\title{
Ultrawideband Antennas: Growth and Evolution
}

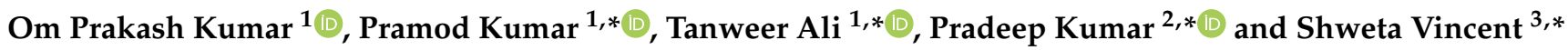 \\ 1 Department of Electronics and Communication Engineering, Manipal Institute of Technology, \\ Manipal Academy of Higher Education, Manipal 576104, India; omprakash.kumar@manipal.edu \\ 2 Discipline of Electrical, Electronic and Computer Engineering, University of KwaZulu-Natal, \\ Durban 4041, South Africa \\ 3 Department of Mechatronics Engineering, Manipal Institute of Technology, Manipal Academy of \\ Higher Education, Manipal 576104, India \\ * Correspondence: p.kumar@manipal.edu (P.K.); tanweer.ali@manipal.edu (T.A.); kumarp@ukzn.ac.za (P.K.); \\ shweta.vincent@manipal.edu (S.V.)
}

check for updates

Citation: Kumar, O.P.; Kumar, P.; Ali

T.; Kumar, P.; Vincent, S.

Ultrawideband Antennas: Growth and Evolution. Micromachines 2022, 13, 60. https://doi.org/10.3390/ mi13010060

Academic Editor: Piotr Kurgan

Received: 6 November 2021

Accepted: 17 December 2021

Published: 30 December 2021

Publisher's Note: MDPI stays neutral with regard to jurisdictional claims in published maps and institutional affiliations.

Copyright: () 2021 by the authors Licensee MDPI, Basel, Switzerland. This article is an open access article distributed under the terms and conditions of the Creative Commons Attribution (CC BY) license (https:// creativecommons.org/licenses/by/ $4.0 /)$.

\begin{abstract}
Narrowband antennas fail to radiate short pulses of nano- or picosecond length over the broader band of frequencies. Therefore, Ultrawideband (UWB) technology has gained momentum over the past couple of years as it utilizes a wide range of frequencies, typically between 3.1-10.6 GHz. UWB antennas have been utilized for various applications such as ground-penetrating radars, disaster management through detection of unexploded mines, medical diagnostics, and commercial applications ranging from USB dongles to detection of cracks in highways and bridges. In the first section of the manuscript, UWB technology is detailed with its importance for future wireless communications systems. In the next section various types of UWB antennas and their design methodology are reviewed, and their important characteristics are highlighted. In section four the concept of a UWB notch antenna is presented. Here various methods to obtain the notch, such as slots, parasitic resonators, metamaterials, and filters are discussed in detail. In addition, various types of important notch antenna design with their technical specifications, advantages, and disadvantages are presented. Finally, the need of reconfigurable UWB notch antennas is discussed in the next section. Here various insight to the design of frequency reconfigurable notch antennas is discussed and presented. Overall, this article aims to showcase the beginnings of UWB technology, the reason for the emergence of notching in specific frequency bands, and ultimately the need for reconfiguring UWB antennas along with their usage.
\end{abstract}

Keywords: ultrawideband (UWB); ultrawideband (UWB) notch antenna; frequency reconfigurable ultrawideband (UWB) notch antenna

\section{Introduction}

The electromagnetic spectrum has a finite range of frequencies that have been used for various forms of communication. The ultrawideband (UWB) has expanded this spectrum of frequencies for a broader range of applications by typically using nanosecond or picosecond pulses, which operate over a wide range of frequencies. Broadband antennas are incapable of passing such pulses for a short time period, leading to dispersion and distorted communication. Therefore, UWB technology has gained momentum over the past couple of years. The Federal Communications Commission (FCC) [1] defines a UWB spectrum as having a fractional bandwidth of typically greater than 0.2 , where fractional bandwidth is defined by Equation (1).

$$
\text { Fractional Bandwidth }=2 \times \frac{\left(f_{\mathrm{H}}-f_{\mathrm{L}}\right)}{\left(f_{\mathrm{H}}+f_{\mathrm{L}}\right)}
$$

where the upper $10 \mathrm{~dB}$ cut-off frequency is denoted by $f_{\mathrm{H}}$ and the lower $10 \mathrm{~dB}$ cut-off frequency is denoted by $f_{\mathrm{L}}$. 
An alternate definition of UWB technology requires the waveforms to have an absolute bandwidth of greater than $500 \mathrm{MHz}$. The pulses used in UWB technology have a short pulse width; they occupy a large bandwidth during transmission. UWB technology is typically used for video streaming, performing movie transfers, camera downloads, printing files on printers, and MP3 file transfers. However, the range of UWB pulses is limited from a few meters to a maximum of $50 \mathrm{~m}$. Their speed ranges from typically $100 \mathrm{Kbps}$ used in wireless sensor networks (WSN) to other higher speed communications typically of 1 Gbps.

The UWB technology has created a boom in the field of communication by proving its vitality in several applications viz., ground penetrating radar (GPR) for emergency communication during earthquakes or avalanches, detection of unexploded mines, health check of civil engineering structures such as highways and buildings, body area networks (BAN) and detection of water in subsurface soil layers for effective agricultural practices.

This article is arranged as follows. Section 2 describes the inception of applications that use the UWB technology for communication. Section 3 elaborates on the different designs of UWB antennas from 2000 to date. Section 4 presents an exhaustive survey of UWB notched antenna in order to mitigate the electromagnetic interferences (EMI) between the sub-bands. Since their inception, Section 5 presents the concept of reconfigurable UWB antennas and showcases the latest state-of-the-art antenna architectures.

\section{UWB Antenna Technology}

In [2], the authors have described the design of a bistatic synthetic aperture radar system for communication overboard a satellite. They used two antennae, one for transmission and the other for the reception of data with typical values of gain between $10 \mathrm{~dB}$ to $20 \mathrm{~dB}$. The BISSAT (BIstatic Sar SATellite) antenna proposed was designed to work in the C-band. In [3], the authors outlined the issues that were faced for the usage of global positioning systems (GPS) aboard satellites. One of the primary concerns which ultimately paved the way for the need for UWB communication was the need to provide resilience to radio interference, i.e., for example, the International Telecommunication Union (ITU) had already designated the $2025 \mathrm{MHz}-2110 \mathrm{MHz}$ for Earth to space communication, and this frequency range interfered with terrestrial radio communication bands. This issue was therefore paving the way for UWB communication. In [4] the author described one of the preliminary usages of UWB communication which was for the detection of targets at sea. Their proposed technique utilized the characteristic of a large bandwidth of UWB antennas to remove the sea clutter and improve the target to clutter ratio for effectively detecting a target. In [5] authors also presented the potential of the usage of UWB technology for the future to enable ad hoc ubiquitous communication. The authors in [6,7] showcased a study conducted by Wireless World Research Forum (WWRF) on the need for new wireless interfaces and issues related to exhaustion of the then spectrum of $3 \mathrm{G}$ communication. This was a leading piece of research for the advent of UWB communications.

The usage of UWB technology for car antennae used for navigation and other forms of communication was demonstrated by [8]. Both the antennae used for mobile and navigation communication were spiral in structure which operated at $350 \mathrm{MHz}$ and $800 \mathrm{MHz}$, respectively. A significant application of the UWB technology was presented in [9] in the form of ground-penetrating radar (GPR). The authors of the article used a dielectric rod antenna that operated between the $1 \mathrm{GHz}$ to $6 \mathrm{GHz}$ frequency range, resulting in weak antenna-ground interaction. This enabled the novel design to be used for GPR applications. On similar lines in [10], the authors designed a Vee dipole antenna with resistive loads for UWB GPR applications. The wide range of frequency operations ranged from $500 \mathrm{MHz}-8 \mathrm{GHz}$.

In [11] author presents a revolutionary article that proved the ability of UWB communication systems to coexist with Fixed Wireless Access (FWA) indoor systems operating in the frequency range of $3.5 \mathrm{GHz}$ to $5 \mathrm{GHz}$. In [12], the authors investigated the effects of UWB technology on the existing $3 \mathrm{G}$ Wi-Fi networks. Their study showed through statistical 
analysis that if the UWB technology were not rolled out properly, the Wi-Fi throughput would be negatively impacted by $20 \%$.

In the article [13], the authors have designed an adaptable ultrawideband wearable antenna for WBAN applications. The antenna design comprises a textile jeans substrate with a copper tape for the radiator patch and the ground plane. The proposed antenna showcases an optimum S11 value and radiation pattern under various bending conditions. The efficiency of the antenna in terms of return loss has been tested for planar and bending configurations. The antenna has an operating bandwidth between $2.2 \mathrm{GHz}$ to $17 \mathrm{GHz}$ for planar configuration. For bending configuration, the antenna radiated between $1 \mathrm{GHz}$ to $1.5 \mathrm{GHz}$. For both configurations, there is a variation in the antenna twist states based on the direction of the twist. The radiation pattern is more stable along the Y-axis bending as opposed to the $\mathrm{X}$-axis bending. In the article [14], the authors have designed a monopole antenna to diagnose a specific form of skin cancer using radiography. The proposed antenna has a dimension of $(36 \times 48 \times 6.12) \mathrm{mm}$ with an impedance bandwidth $(8.2-13) \mathrm{GHz}$. The gain of the antenna is $7.04 \mathrm{dBi}$. The antenna has performed well in both planar and bending configurations. For the antenna with AMC, the radiation rate at the rear is lower when compared to the independent antenna. Further, the same has been noticed when the AMC antenna is placed on the body. Due to the body's interference and absorption of energy, the AMC antenna's gain when mounted on the body is lower when compared to the AMC antenna in free space.

In the article [15], the authors have presented the design of a flexible UWB antenna that showcases a bandwidth of $3.7 \mathrm{GHz}$ to $10.3 \mathrm{GHz}$. With dimensions of $80 \mathrm{~mm} \times 67 \mathrm{~mm}$, the proposed antenna has a microstrip patch with two arc-shaped patches. This forms the entire radiator. Suppression of antenna loading due to the underlying body tissues has been achieved by using a full ground plane at the bottom of the antenna. The antenna performance has been studied in free space as well as human body environments. A VSWR of below 2 has been achieved in both environments. The VSWR remains constant even in case of bending of the antenna. Peak gain of around $4.53 \mathrm{dBi}$ has been achieved with an overall efficiency of $<60 \%$. The SAR also conforms to the requirement of lower than $2 \mathrm{~W} / \mathrm{kg}$ with values of $0.147,0.174$, and 0.09 at $5 \mathrm{GHz}, 7 \mathrm{GHz}$, and $9 \mathrm{GHz}$, respectively. However, slight discrepancies have been noted in simulated and actual measured parameters due to faulty fabrication. In the article [16], the authors have designed a coplanar waveguide (CPW) fed flexible UWB antenna which uses Mu-negative metamaterial, which can be used for wearable applications. They have designed an UWB antenna with $50 \mathrm{~mm} \times 45 \mathrm{~mm}$ dimensions by fabricating it on two materials, namely, flexible FR4 and semi-flexible Rogers RT/duroid 5880. A bandwidth of $7.2 \mathrm{GHz}$ to $9.2 \mathrm{GHz}$ has been achieved. The overall gain of the antenna has been improved to $8 \mathrm{dBi}$ by designing a $3 \times 3$ array. SAR values of $0.3 \mathrm{~W} / \mathrm{kg}$ and $0.1 \mathrm{~W} / \mathrm{kg}$ have been achieved for $3 \mathrm{GHz}$ and $10 \mathrm{GHz}$, respectively.

Authors in [17] have presented the design of a textile antenna for wearable medical imaging applications. The antenna has been designed in a triangular shape with parallel slots to enhance radiation in the UWB range of frequencies. Flexible polyester has been used for constructing the antennas. In [18], the authors presented yet another novel application of UWB antennas for Wireless Body Area Networks (WBAN). The antennas designed proved their usage owing to their little thickness of around $0.5 \mathrm{~mm}$. The authors proposed two physical designs of antennas, viz., a coplanar UWB disc monopole and UWB annular slot antennas. The antennas operate in the 3.11-10.6 GHz frequency range. In [19] authors also investigated the usage of UWB technology for WBAN applications. They developed a novel Swastika slot-ultra-wideband (SS-UWB) patch antenna, which operated in the frequency range of 3.1-10.6 GHz. Also presented the design of a high-fidelity UWB antenna for WBAN applications. They implemented a structure with two layers of patches with a $2 \mathrm{~mm}$ thick substrate to enable radio communication over a range of $1 \mathrm{~m}$. In [20], the authors present yet another flexible UWB antenna used for BAN. It is created by integrating a conductive tissue-like fabric on polydimethylsiloxane (PDMS) substrate. The antenna operates at a frequency range of $2.0-2.5 \mathrm{GHz}$ with an efficiency of $70 \%$. Authors in [21] 
designed a UWB of $4.68 \mathrm{~mm}$ thickness to operate in the frequency range of $4.33 \mathrm{GHz}$ to13 GHz. The authors have reported that the specific absorption rate (SAR) values of the antenna reduce by $98.3 \%$ when metamaterial is used as the substrate.

Hossain et al. in [22] have designed a bird face monopole ultrawideband antenna. It showcases an operating bandwidth of 3.10-12.30 GHz. The antenna gain variations are not uniform. The cross-polarization levels are not discussed. In [23] authors proposed the usage of antenna arrays aka vector antennas to increase the bandwidth of UWB communication systems. They designed an antenna array comprising a loop antenna and two orthogonal bowtie antennas that worked in a $3.6-8.5 \mathrm{GHz}$ frequency range. Moreover, UWB antennas have also been designed for USB dongle applications [24]. The antenna used is a U-shaped monopole antenna with a metal plate with a ground plane made of foam. The size of the antenna is relatively compact for the purpose of the dongle. The antenna design provides an ultra-wide bandwidth of around $7.6 \mathrm{GHz}$.

In [25], authors described a yet another revolutionary application of UWB technology: the designed sensing through the wall systems. This proved to be an integral technology for military applications in urban terrain. The authors examined the feasibility of UWB signals through wall imaging in [26]. The authors used UWB noise waveforms as a probing signal with the principle of heterodyne correlation to image objects behind a wall successfully. Authors in [27] employed the short-term Fourier transform (STFT) of UWB frequencies to sense targets across foliage. Similarly, in [28,29], the authors provided an insight on the usage of support vector machine (SVM) in integration with UWB signals and Singular value decomposition (SVD) algorithm, respectively, to classify human presence through the foliage.

Authors in $[30,31]$ investigated the usage of UWB technology for mobile terminals. The former designed a stubby antenna that resonated in a band of $1.0-6.0 \mathrm{GHz}$, and the latter provided a survey of reconfigurable adaptive CMOS circuits using UWB signals for $4 \mathrm{G}$ mobile applications. The usage of UWB sensor networks for target localization in the mining industry was investigated in [32].

As the UWB technology began carving its niche in the wireless domain, [33] presented a study of its interference with WiMAX systems typically in $2.5-3.5 \mathrm{GHz}$ frequencies. They concluded that UWB signals with an Effective Isotropic Radiated Power (EIRP) of $83 \mathrm{dBm} / \mathrm{MHz}$ or less for a distance of $1 \mathrm{~m}$ would not pose any interference to WiMAX signals. Authors in [34] showcased the viability of integrating Bluetooth with UWB technology over the MAC layer and PHY layer of transmission of signals.

The indoor and location tracking applications in harsh environments using UWB technology were investigated by [35,36], respectively. In [35], authors stated that for mission critical scenarios such as rescue requiring drastic measures for mission planning and execution, it was essential to have systems that could operate in a wide range of frequencies for which the UWB technology was most suited. In [36] the author extended to present the feasibility of UWB signals for tracking critical resources in construction environments. It is used as a support tool for managing construction sites.

In [37-40], the authors proved the feasibility and significance of UWB signals to penetrate through foliage/debris in a critical situation such as an earthquake or a dilapidated coal mine and detect the presence of life in humans. The fundamental advantage these researchers tapped in was the excellent penetration capability of UWB signals.

UWB technology was also proposed to be used in the medical field for Microwave Radiology Imaging (MRI) application in [41]. The authors presented a Slotted Triangular Flared (STF) patch mounted on a substrate of Teflon. An in-phase reflector increased the bandwidth of the system, causing it to work in the UWB range of frequencies. In [42], the authors have revolutionized the medical realm by designing a UWB antenna with slots for breast cancer detection. The advantage of using UWB for microwave imaging is that it provides non-ionizing signals with large bandwidth. A mini rectangular patch antenna has been used for this purpose. 
UWB technology has also been proposed for detecting voids in specimens of concrete [43]. This has been achieved by designing a Vivaldi antenna to operate within a frequency range of 1-30 GHz. The designed antenna has obtained high resolution images.

The authors in [44] showcased the feasibility of UWB communication systems to become an integral part of $5 \mathrm{G}$ wireless systems. A rake receiver for indoor applications has been designed to mitigate multipath effects and provide throughputs.

UWB technology has also found its application in Near Field imaging applications used in Synthetic Aperture Radar (SAR) [45]. The authors of this article have designed an antenna with two dipoles in the orthogonal configuration with elliptical arms and a modified configuration for feeding. The antenna has been used for the application of monitoring perforations in an oil well wall. In [46] authors have examined the feasibility of living in smart homes integrating UWB technology with deep learning for the elderly. Recognition of activities performed by seniors is done using three UWB radars along with a deep learning model and a voting system. Table 1 describes the emergence of UWB technology and its applications in Section 2 above. 
Table 1. The emergence of UWB technology and its applications.

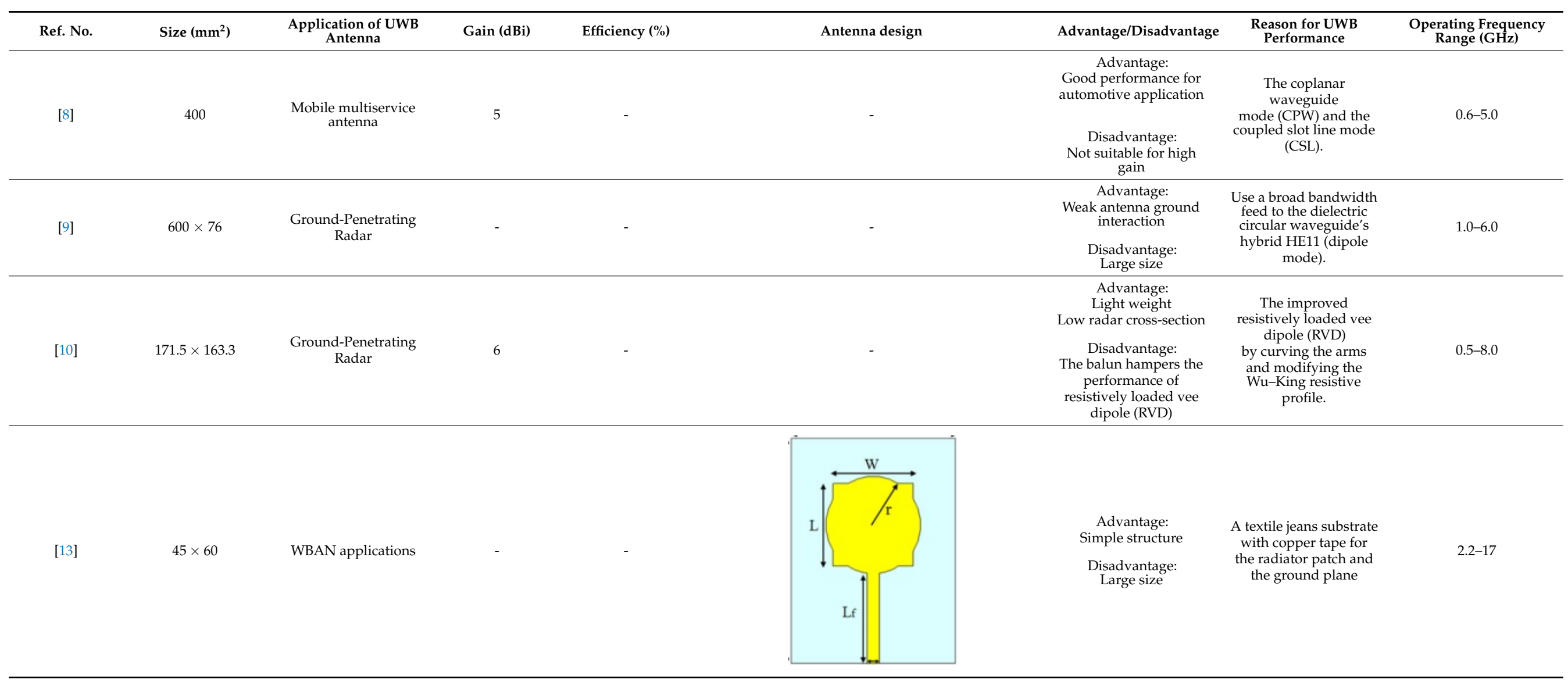


Table 1. Cont.

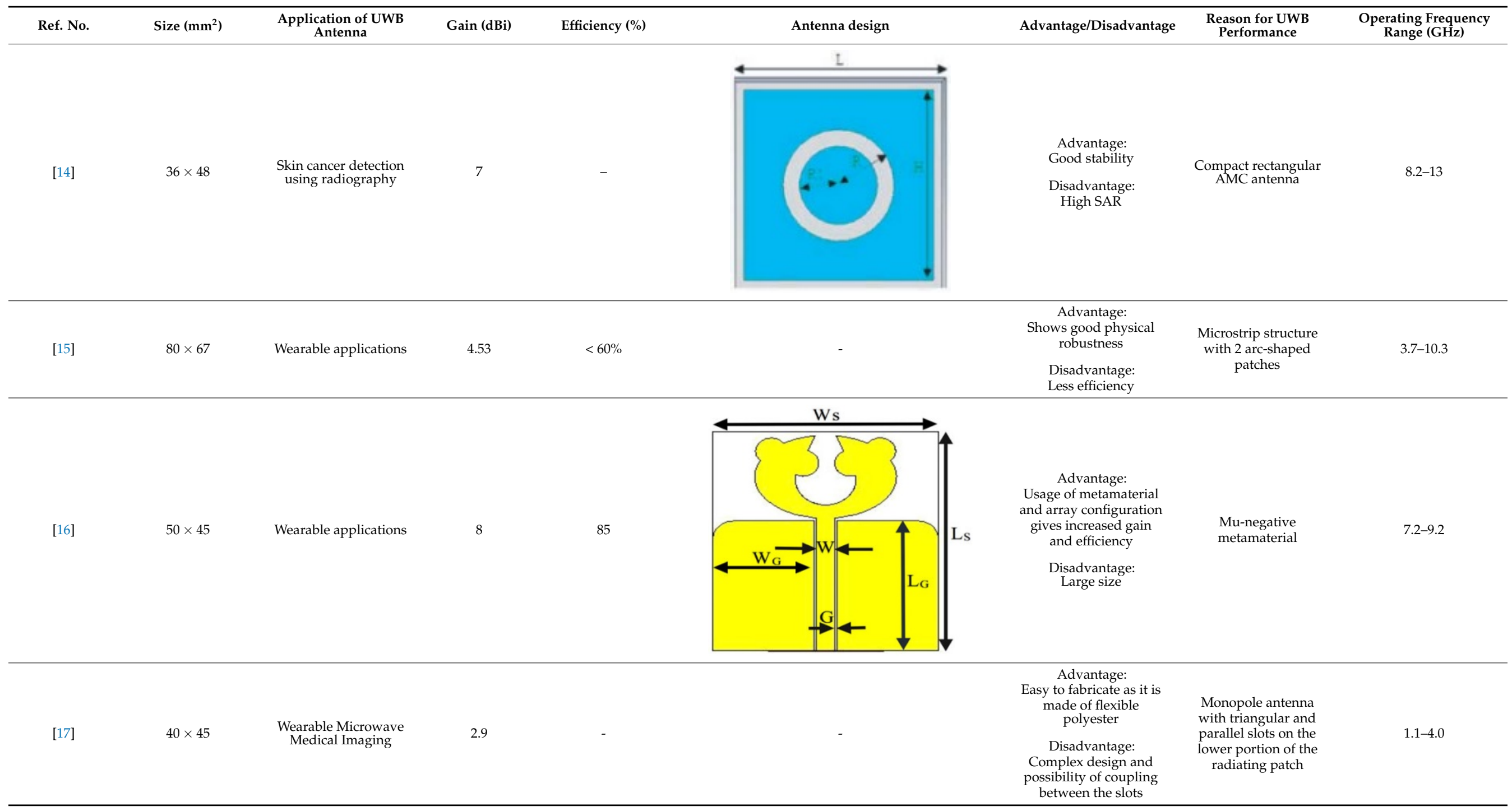


Table 1. Cont.

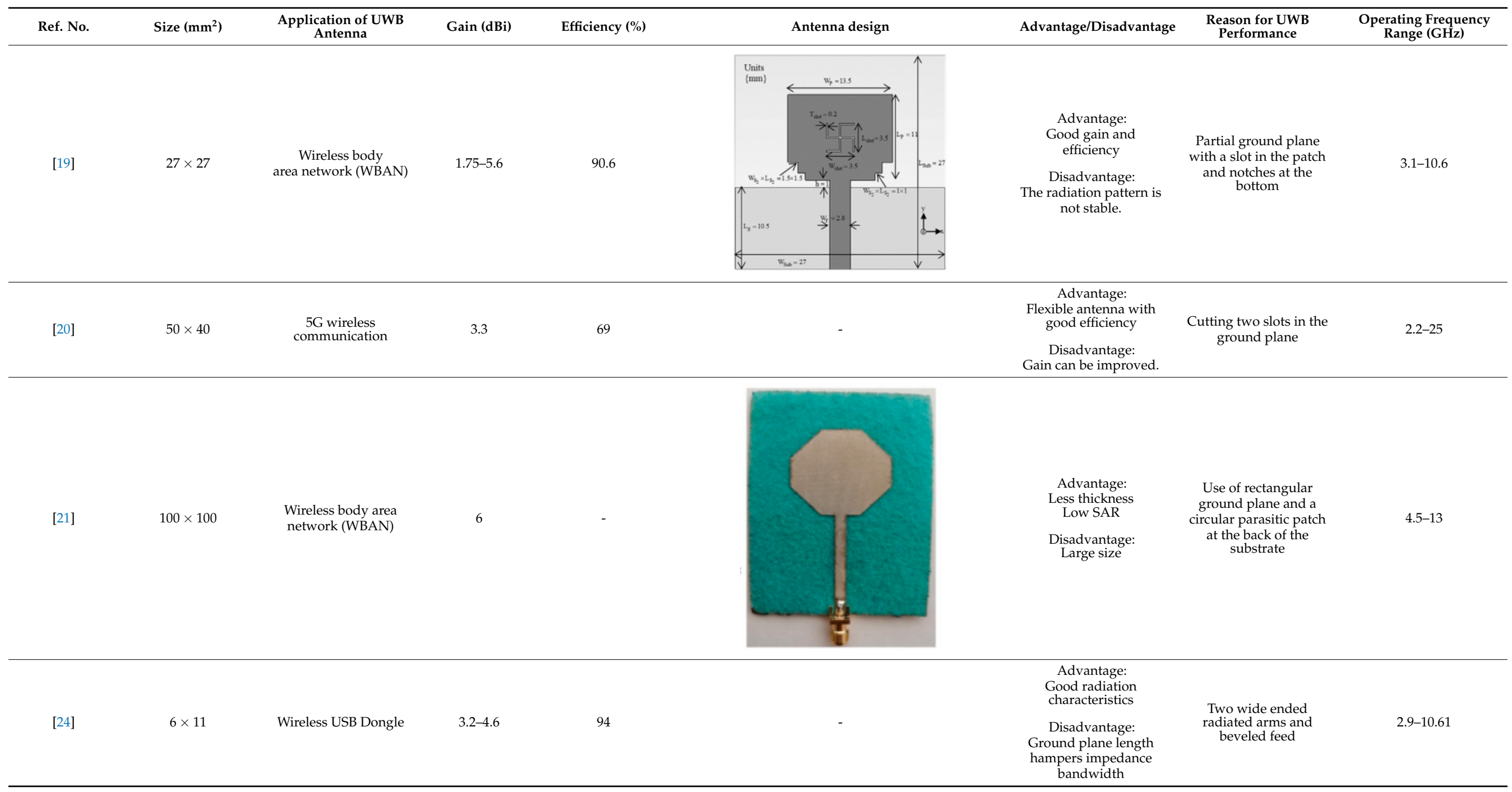


Table 1. Cont.

\begin{tabular}{|c|c|c|c|c|c|c|c|c|}
\hline Ref. No. & Size $\left(\mathrm{mm}^{2}\right)$ & $\begin{array}{c}\text { Application of UWB } \\
\text { Antenna }\end{array}$ & Gain (dBi) & Efficiency (\%) & Antenna design & Advantage/Disadvantage & $\begin{array}{c}\text { Reason for UWB } \\
\text { Performance }\end{array}$ & $\begin{array}{l}\text { Operating Frequency } \\
\text { Range (GHz) }\end{array}$ \\
\hline [30] & $5 \times 8$ & Mobile phone & - & 88 & & $\begin{array}{c}\text { Advantage: } \\
\text { Good impedance } \\
\text { matching and efficiency } \\
\text { Disadvantage: } \\
\text { Design complexity }\end{array}$ & $\begin{array}{l}\text { Utilization of tapered } \\
\text { structure }\end{array}$ & $0.8-6$ \\
\hline [40] & $33.4 \times 34.3$ & $\begin{array}{l}\text { Human respiration and } \\
\text { heart rate detection }\end{array}$ & 14 & - & & $\begin{array}{l}\text { Advantage: } \\
\text { High Gain antenna } \\
\text { Disadvantage: } \\
\text { The radiation pattern } \\
\text { can be improved. }\end{array}$ & $\begin{array}{l}\text { Doppler radar } \\
\text { technique }\end{array}$ & 10 \\
\hline [41] & $32 \times 28$ & $\begin{array}{l}\text { Microwave Radiology } \\
\text { Imaging (MRI) } \\
\text { applications }\end{array}$ & 6 & - & & $\begin{array}{l}\text { Advantage: } \\
\text { Good performance for } \\
\text { MRI applications } \\
\text { Disadvantage: } \\
\text { Large size }\end{array}$ & $\begin{array}{l}\text { Slotted Triangular } \\
\text { Flared (STF) patch }\end{array}$ & $7.8-15$ \\
\hline [43] & $202 \times 96$ & $\begin{array}{l}\text { Detection of Void } \\
\text { Inside } \\
\text { Concrete Specimens }\end{array}$ & 9.5 & - & - & $\begin{array}{c}\text { Advantage: } \\
\text { It gives high-quality } \\
\text { image of lost materials. } \\
\text { Disadvantage: } \\
\text { Large size }\end{array}$ & $\begin{array}{l}\text { Use of tapered ground } \\
\text { plane }\end{array}$ & $1-30$ \\
\hline [45] & $48.6 \times 48.6$ & $\begin{array}{l}\text { Near-Field synthetic } \\
\text { aperture radar (SAR) } \\
\text { Imaging }\end{array}$ & 3 & - & - & $\begin{array}{c}\text { Advantage: } \\
\text { High impedance } \\
\text { bandwidth and planar } \\
\text { structure } \\
\text { Disadvantage: } \\
\text { Less gain }\end{array}$ & $\begin{array}{l}\text { circularly polarized } \\
\text { crossed dipole antenna } \\
\text { with elliptical arms } \\
\text { vacated by rotated } \\
\text { elliptical } \\
\text { slot. }\end{array}$ & $1.6-7.2$ \\
\hline
\end{tabular}

Note: - indicates not applicable. 


\section{Progress/Emergence of Design of UWB Antenna}

The need for UWB technology was born with the idea of a system encompassing a wide bandwidth of operation and very low interference with existing technologies such as Wi-Fi, WiMAX, and GPS. Section 1 described the varied applications developed over the years using UWB antennas due to their superior bandwidth, gain, and low interference features as opposed to other wireless technologies. Table 2 lists the important UWB antennas proposed in the literature with their design specification, advantage and disadvantages.

In [47], the authors have conducted an extensive survey on the promises offered by the UWB radio technology (UWB-RT), the primary one being to reduce the problem of a narrow spectrum. The authors have proposed to harness the ability of UWB technology to work in conjunction with other $3 \mathrm{G}$ wireless technologies.

In [48], the author designed a UWB antenna to remove the scattering of waves using resistive sheets for a slot line bowtie hybrid (SBH) antenna. The authors have employed the Genetic algorithm (GA) to stabilize the antenna's beamwidth. A lower radar cross-section (RCS) is obtained by exploiting the fact that resistive sheets are almost transparent of EM fields.

In [49], the authors have also been able to obtain a uniform radiation band over the entire bandwidth with a constant gain of $10 \mathrm{~dB}$ by designing a diplexer with two patch antennas stacked one over the other. In [50], authors have proposed a planar monopole antenna that is shorted and has a bevel. Their design demonstrates an increase in bandwidth by combining beveling along with shorting the monopole antenna. A bandwidth of 50 to 1 from $300-15,000 \mathrm{MHz}$ is achieved by [51] by employing the genetic algorithm to generate the shape of the antenna and the impedance loads connected in series.

The authors in [52] have analyzed the usage of the finite-difference time-domain (FDTD) method to design horn-fed bowtie antennas (HFB) to work in the UWB frequency spectrum. A wide bandwidth has been achieved, making these antennas suitable for GPR applications. In [53], authors have investigated the need for slotting in the conventional UWB antennas. They utilized the planar inverted cone antenna (PICA), which is used in the UWB frequency range. The PICA antennas are modified by inserting two holes of the circular shape to change the flow of current on the metal disk, in turn improving the bandwidth of the radiation. In [54], authors have also investigated the usage of the FDTD technique to design two conical plane transmission lines. Their surge impedance has been calculated for various geometries and various dielectric loads. These antennas radiate in the UWB range and are suitable for GPR applications. A circular planar monopole with microstrip line feeding has been designed in $[55,56]$. Their antenna showcases a return loss of $10 \mathrm{~dB}$ with a stable radiation pattern. The impedance characteristic of an exponentially tapered UWB TEM horn antenna is improved using a balun of microstrip-type in [57]. The proposed design showcases a bandwidth three times more than the conventional linearly tapered TEM horn. In [58], the authors have designed a planar UWB antenna with an elliptical radiator feed using a microstrip line. Both the radiator and the feed line are mounted on the same ground plane. The authors of this article have been able to generate a bandwidth of $110.9 \%$ gain from $1.34 \mathrm{dBi}$ to $5.43 \mathrm{dBi}$ within an operating frequency range from 3-10.6 GHz. UWB operation is achieved using magnetic coupling of two sectorial loop antennas which are arranged symmetrically in [59]. After optimizing the design, a VSWR of around 2.2 across 8.5:1 frequency is achieved. In [60], a trident-shaped feed has achieved UWB characteristics with a bandwidth of about $10 \mathrm{GHz}$. This feed is integrated with a square monopole in the planar structure fabricated on a single metal plate. 
Table 2. The emergence of design of UWB antenna

\begin{tabular}{|c|c|c|c|c|c|c|c|}
\hline Reference No. & Size $\left(\mathrm{mm}^{2}\right)$ & Gain (dBi) & Efficiency & Advantage/Disadvantage & Reason for UWB Performance & Design Methodology & $\begin{array}{c}\text { Operating Frequency } \\
\text { Range (GHz) }\end{array}$ \\
\hline [48] & - & - & - & $\begin{array}{c}\text { Advantage: } \\
\text { Good impedance matching and compact } \\
\text { in size } \\
\text { Disadvantage: } \\
\text { Absorber treatment is required in E and } \\
\text { H planes to achieve desired performance }\end{array}$ & Bowtie TEM horn & Genetic algorithm & $3.1-10.6$ \\
\hline [50] & $141.4 \times 141.4$ & - & - & $\begin{array}{c}\text { Advantage: } \\
\text { High bandwidth } \\
\text { Stable radiation pattern } \\
\text { Disadvantage: } \\
\text { Large size }\end{array}$ & introduction of a bevel & $\begin{array}{l}\text { Cutting slots in each side } \\
\text { of the } \\
\text { planar element }\end{array}$ & $0.8-10.5$ \\
\hline [51] & $1220 \times 1220$ & - & $20-100$ & $\begin{array}{c}\text { Advantage: } \\
\text { Elliptical polarization and near } \\
\text { hemispherical coverage } \\
\text { Disadvantage: } \\
\text { Low efficiency at lower frequencies }\end{array}$ & $\begin{array}{l}\text { A genetic antenna consisting of a set of } \\
\text { wires connected in series and with } \\
\text { impedance loads }\end{array}$ & genetic antenna & $0.3-15$ \\
\hline [52] & $2550 \times 2550$ & - & - & $\begin{array}{c}\text { Advantage: } \\
\text { Important design characteristics can be } \\
\text { measured using this FTDT model } \\
\text { Disadvantage: } \\
\text { Complex antenna }\end{array}$ & $\begin{array}{l}\text { planar bowtie dipole with the feed point } \\
\text { being raised off the ground }\end{array}$ & FDTD technique & $3.1-10.6$ \\
\hline [56] & $50 \times 42$ & 8 & - & $\begin{array}{c}\text { Advantage: } \\
\text { Good frequency characteristics in the } \\
\text { UWB range } \\
\text { Disadvantage: } \\
\text { Poor polarization }\end{array}$ & $\begin{array}{l}\text { Circular disc monopole } \\
\text { fed by microstrip line }\end{array}$ & $\begin{array}{l}\text { Use of the feed gap, the } \\
\text { width of the ground plane, } \\
\text { and the size of the disc. }\end{array}$ & $2.6-10.1$ \\
\hline [57] & $1000 \times 3$ & 11 & - & $\begin{array}{c}\text { Advantage: } \\
\text { Improves bandwidth of TEM horn } \\
\text { antenna } \\
\text { Disadvantage: } \\
\text { High cross-polarization }\end{array}$ & $\begin{array}{l}\text { TEM horn antenna with exponential } \\
\text { tapering with a balun of microstrip type }\end{array}$ & $\begin{array}{l}\text { Use of linearly tapered and } \\
\text { exponentially tapered } \\
\text { structure }\end{array}$ & $0.6-15.7$ \\
\hline [59] & $200 \times 200$ & 8 & - & $\begin{array}{c}\text { Advantage: } \\
\text { Excellent polarization and good } \\
\text { impedance bandwidth } \\
\text { Disadvantage: } \\
\text { Gain decreases from } 6 \mathrm{GHz} \text { to } 10 \mathrm{GHz}\end{array}$ & $\begin{array}{l}\text { Magnetic coupling of symmetrical } \\
\text { sectoral antennas of loop shape }\end{array}$ & Two Sectors & $2-16$ \\
\hline
\end{tabular}


Table 2. Cont.

\begin{tabular}{|c|c|c|c|c|c|c|c|}
\hline Reference No. & Size $\left(\mathrm{mm}^{2}\right)$ & Gain (dBi) & Efficiency & Advantage/Disadvantage & Reason for UWB Performance & Design Methodology & $\begin{array}{c}\text { Operating Frequency } \\
\text { Range (GHz) }\end{array}$ \\
\hline [60] & $150 \times 150$ & 7 & - & $\begin{array}{c}\text { Advantage: } \\
\text { Easily fabricated using the single metal } \\
\text { plate and } \\
\text { Cost-effective } \\
\text { Disadvantage: } \\
\text { Large size }\end{array}$ & Trident-Shaped Feeding Strip & $\begin{array}{l}\text { Combination of square } \\
\text { planar } \\
\text { monopole antenna with a } \\
\text { trident-shaped feeding } \\
\text { strip }\end{array}$ & $1.4-11.4$ \\
\hline [61] & 1000 & 8 & - & $\begin{array}{c}\text { Advantage: } \\
\text { It doesn't need an anechoic chamber for } \\
\text { measurement } \\
\text { Sensitivity to noise is low } \\
\text { Disadvantage: } \\
\text { Efficiency is low }\end{array}$ & $\begin{array}{l}\text { Use of conducting wire antenna as a pair } \\
\text { of scissors }\end{array}$ & $\begin{array}{l}\text { scissors antenna consists } \\
\text { of conducting wires }\end{array}$ & $0.2-4$ \\
\hline [62] & $6.5 \times 66.3$ & 6 & - & $\begin{array}{c}\text { Advantage: } \\
\text { Uniform radiation pattern and less } \\
\text { distortion in the baseband signal } \\
\text { Disadvantage: } \\
\text { The tradeoff between antenna } \\
\text { performance and miniaturization }\end{array}$ & $\begin{array}{l}\text { The tapered-slot feed acts transform the } \\
\text { impedance and directs the maximum } \\
\text { radiation from the slot line to the } \\
\text { radiating slot }\end{array}$ & Tapered slot & $3.1-10.6$ \\
\hline [63] & $40 \times 38$ & 7 & - & $\begin{array}{l}\text { Advantage: } \\
\text { Omnidirectional radiation pattern } \\
\text { Disadvantage: } \\
\text { The time-domain analysis is not } \\
\text { performed }\end{array}$ & $\begin{array}{l}\text { CPW fed with a U-shaped tuning stub } \\
\text { and elliptical slot }\end{array}$ & $\begin{array}{l}\text { Elliptical slot with U } \\
\text { shaped stub }\end{array}$ & $3.1-10.6$ \\
\hline [64] & $136.2 \times 66.4$ & 12 & - & $\begin{array}{l}\text { Advantage: } \\
\text { High gain } \\
\text { Disadvantage: } \\
\text { Large size }\end{array}$ & $\begin{array}{l}\text { Double exponential tapered slot on LCP } \\
\text { gives end-fire radiation in UWB range of } \\
\text { frequency }\end{array}$ & $\begin{array}{l}\text { Double exponential } \\
\text { tapered slot }\end{array}$ & $3.1-10.6$ \\
\hline [65] & $126 \times 60$ & - & - & $\begin{array}{c}\text { Advantage: } \\
\text { Stable radiation pattern up to } 6 \mathrm{GHz} \\
\text { Disadvantage: } \\
\text { Pattern not stable at higher frequencies }\end{array}$ & $\begin{array}{l}\text { planar rectangular monopole antenna } \\
\text { with a sleeved transmission line with the } \\
\text { displaced feed point }\end{array}$ & $\begin{array}{l}\text { sleeved transmission line- } \\
\text { fed rectangular } \\
\text { planar disc monopole } \\
\text { antenna with a small } \\
\text { ground } \\
\text { plane } \\
\end{array}$ & $0.5-9.0$ \\
\hline [66] & $30 \times 11.5$ & 2.2 & - & $\begin{array}{c}\text { Advantage: } \\
\text { Suitable for mm-wave applications } \\
\text { Disadvantage: } \\
\text { Less gain }\end{array}$ & $\begin{array}{l}\text { Resonators of varying lengths are added } \\
\text { along the feedline. }\end{array}$ & Stepped slots & $6-22$ \\
\hline [67] & $120.3 \times 24.8$ & 7 & 80 & $\begin{array}{c}\text { Advantage: } \\
\text { Large bandwidth and low pulse } \\
\text { distortion } \\
\text { Disadvantage: } \\
\text { Large size and complex structure }\end{array}$ & $\begin{array}{l}\text { A tapered loop is formed from the CPW } \\
\text { to CPS to increase the operating } \\
\text { bandwidth }\end{array}$ & Circular tapered slot & $3.1-10.6$ \\
\hline
\end{tabular}


Table 2. Cont.

\begin{tabular}{|c|c|c|c|c|c|c|c|}
\hline Reference No. & Size $\left(\mathrm{mm}^{2}\right)$ & Gain (dBi) & Efficiency & Advantage/Disadvantage & Reason for UWB Performance & Design Methodology & $\begin{array}{c}\text { Operating Frequency } \\
\text { Range (GHz) }\end{array}$ \\
\hline [68] & $62 \times 52$ & 6 & - & $\begin{array}{c}\text { Advantage: } \\
\text { Impedance bandwidth of } 144.8 \% \text { and } \\
\text { stable radiation pattern } \\
\text { Disadvantage: } \\
\text { Large size }\end{array}$ & $\begin{array}{l}\text { A circular slot with a new moon-shaped } \\
\text { strip connected to the feed line causes a } \\
\text { wide bandwidth. This is created to } \\
\text { stabilize the radiation pattern at higher } \\
\text { frequencies. }\end{array}$ & $\begin{array}{l}\text { Circular slot with } \\
\text { moon-shaped strip }\end{array}$ & $2.4-11$ \\
\hline [69] & $30 \times 46$ & 3.8 & - & $\begin{array}{c}\text { Advantage: } \\
\text { High efficiency and good } \\
\text { omnidirectional radiation pattern } \\
\text { Disadvantage: } \\
S_{11}>-10 \mathrm{~dB} \text { for } 3.1 \text { to } 4 \mathrm{GHz}\end{array}$ & $\begin{array}{l}\text { Beveling the bottom border of planar } \\
\text { monopole antenna }\end{array}$ & $\begin{array}{l}\text { Slot cut in the ground } \\
\text { plane }\end{array}$ & 3.1-12 \\
\hline [70] & $160 \times 108$ & 18 & - & $\begin{array}{c}\text { Advantage: } \\
\text { Good gain and directivity. } \\
\text { Negligible cross-polarization } \\
\text { Disadvantage: } \\
\text { Weak phase dispersivity }\end{array}$ & $\begin{array}{l}\text { Slot etching on the ground plane with a } \\
\text { central point feed }\end{array}$ & leaky slot line & $4-40$ \\
\hline [71] & $50 \times 46$ & 1.54 & - & $\begin{array}{c}\text { Advantage: } \\
\text { Simple structure and stable radiation } \\
\text { pattern } \\
\text { Disadvantage: } \\
\text { Less gain and large size }\end{array}$ & $\begin{array}{l}\text { The curves of the antenna edge by a } \\
\text { binomial function which gives the wider } \\
\text { impedance bandwidth }\end{array}$ & Use of a binomial function & $2.5-10.9$ \\
\hline [73] & $90 \times 90$ & 8.2 & - & $\begin{array}{c}\text { Advantage: } \\
\text { Minimum ringing and dispersion of } \\
\text { pulse in the time domain } \\
\text { Disadvantage: } \\
\text { Large dimension }\end{array}$ & $\begin{array}{c}\text { Elliptical } \\
\text { monopole antenna }\end{array}$ & $\begin{array}{c}\text { Elliptical } \\
\text { monopole antenna }\end{array}$ & $12-12.6$ \\
\hline [74] & $47 \times 45$ & 9.9 & - & $\begin{array}{c}\text { Advantage: } \\
\text { Good gain } \\
\text { Disadvantage: } \\
\text { The radiation pattern is moderate. }\end{array}$ & Suspended (Plate antenna) structure & $\begin{array}{l}\text { It consists of four top } \\
\text { plates connected to a } \\
\text { bottom plate using four } \\
\text { vertical strips. }\end{array}$ & $3.1-4.8$ \\
\hline [75] & $100 \times 100$ & 5.2 & - & $\begin{array}{c}\text { Advantage: } \\
\text { Simple design, cost-effective, and } \\
\text { mechanically robust } \\
\text { Disadvantage: } \\
\text { Large size }\end{array}$ & $\begin{array}{l}\text { Suspended plate antenna with the } \\
\text { shorting wall } \\
\text { together with the L-probe feed }\end{array}$ & Parasitic L-shaped plate & $3-12$ \\
\hline
\end{tabular}


Table 2. Cont.

\begin{tabular}{|c|c|c|c|c|c|c|c|}
\hline Reference No. & Size $\left(\mathrm{mm}^{2}\right)$ & Gain (dBi) & Efficiency & Advantage/Disadvantage & Reason for UWB Performance & Design Methodology & $\begin{array}{l}\text { Operating Frequency } \\
\text { Range (GHz) }\end{array}$ \\
\hline [76] & $30 \times 8$ & 4 & - & 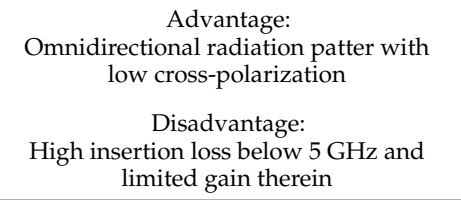 & $\begin{array}{l}\text { The planar monopole has strong vertical } \\
\text { currents, which leads to large impedance } \\
\text { bandwidth. A triangular feeding strip is } \\
\text { used. }\end{array}$ & $\begin{array}{l}\text { Rectangular monopole } \\
\text { with an equal-width } \\
\text { ground } \\
\text { plane }\end{array}$ & $2.7-16.2$ \\
\hline [77] & $30 \times 20$ & 4.13 & - & $\begin{array}{c}\text { Advantage: } \\
\text { Low VSWR, stable gain and linear phase } \\
\text { Disadvantage: } \\
\text { There is a reduction in radiation } \\
\text { efficiency due to an increase in input } \\
\text { impedance in the mid UWB band. }\end{array}$ & $\begin{array}{l}\text { There are electric and magnetic radiators. } \\
\text { Energy stored in matching stubs is } \\
\text { radiated because of the CPW-slot line } \\
\text { transition. }\end{array}$ & Two rectangular slots & $3.1-10.6$ \\
\hline [78] & $71 \times 71$ & 4 & - & $\begin{array}{c}\text { Advantage: } \\
\text { Simple feeding structure and good } \\
\text { bandwidth } \\
\text { Disadvantage: } \\
\text { Large size }\end{array}$ & $\begin{array}{l}\text { The polygonal slot results in bandwidth } \\
\text { enhancement }\end{array}$ & Polygonal slot & $1.8-5.9$ \\
\hline [79] & $24.5 \times 24.5$ & 5.9 & - & $\begin{array}{c}\text { Advantage: } \\
\text { Small size with impedance bandwidth of } \\
122 \% \\
\text { Disadvantage: } \\
\text { The radiation pattern is quite unstable. }\end{array}$ & $\begin{array}{l}\text { Asymmetrical beveled rectangular patch } \\
\text { with a U slot causes enhancement in } \\
\text { bandwidth }\end{array}$ & $\begin{array}{l}\text { Asymmetrical rectangular } \\
\text { patch with U shaped slot }\end{array}$ & $2.9-12.1$ \\
\hline
\end{tabular}

Note: - indicates not applicable. 
The Scissors antenna has been designed by [61] for transient UWB applications. It consists of conducting wires which radiate ultrashort pulses having low dispersion. It has been proven to have a better radiation characteristic in comparison to conventional harmonic measurements. A UWB within the frequency range of $0.5-9 \mathrm{GHz}$ has been designed in [63]. The authors have used a monopole in the shape of a rectangular disc which is fed with a sleeved transmission line with a small ground plane to achieve this high bandwidth. A UWB usable for handset applications with a folded metallic element connected to a printed section has been proposed in [69]. Various paths for current have been created, thereby increasing the dimensions of the antenna. The antenna has a quasiomnidirectional radiation pattern over the entire UWB frequency range of operation.

The UWB leaky lens antenna has been designed in [70], which utilizes the property of Cherenkov radiation occurrence in a slot that is printed in the conjunction of infinite homogeneous dielectrics. This results in a directive antenna that has non-dispersive characteristics.

The binomial function has been used to design the edge of the curve of the planar antenna designed in [71]. Different orders of the binomial function have been used along with varying widths of the gaps between the antenna and the ground plane. The proposed antenna showcases an omnidirectional pattern of radiation in the UWB range of frequencies. In [72], a rod antenna with a metal reflector that operates in the UWB range has been presented. The antenna is fed with a biconical dipole with a microstrip line balun. This design showcases a bandwidth of operation from 3-20 GHz. It also exhibits very less dispersive effects.

A planar UWB elliptical monopole antenna has been presented in [73]. An ellipticity ratio of 1.1 gives a UWB ratio of $12.4: 1$ as opposed to 10.2:1 as of a circular monopole antenna. A suspended plate antenna (SPA) has been designed in [74]. The bottom layer plate is suspended over the ground and has a feed that is tapered towards it. The upper layer has four radiation plates, each connected to the bottom plate using vertical metallic strips. The proposed antenna radiates in the frequency range of 2.8-6 GHz with a stable gain. A UWB plate antenna with a wall for shorting which is attached to the radiator has been presented in [75]. The antenna is excited with an L-shaped plate. Due to the electromagnetic coupling between the feed plate and the radiator, radiation over the UWB range of frequencies has been achieved. The rest of the antennas tabulated in Table 2 illustrate the various characteristics owing to which a UWB performance has been achieved. Table 2 tabulates the designs of simple UWB antennas along with their key design features and radiation characteristics.

As presented in this section, it may be observed that each of the antennas radiates in the UWB range of frequencies without notching in any range of frequencies. However, with the improvement in UWB technology, the need for notching in specific frequencies such as the Wi-Fi, WiMAX was noticed to avoid interference. This led to the emergence of creation of slots of different shapes and sizes in different positions to generate notches. To mitigate the effect of EMI between the other devices operating within the UWB frequency range, Section 4 describes in detail the various literature available for slotted antennas.

\section{The Emergence of UWB Notch Antenna}

UWB systems present the greatest challenge of overcoming interference with narrowband systems due to their wide bandwidth [80]. Existing technologies such as WiMAX, which operates in the range of 3.3-3.7 GHz, Wireless LAN, which operates in the range of 5.15-5.35 GHz, $C$ and $X$ bands of the ITU, which operate in the 7.25-7.75 GHz and 8.025-8.4 GHz, respectively, pose serious possibilities of strong interference to UWB systems. Strong interference due to narrowband systems can result in strong disturbances similar to background noise. This factor of noise increases the power spectral density of the signal, thereby reducing the capacity of the UWB system.

The interference between UWB devices and narrowband devices that hampers the communication systems' overall performance is mitigated using some novel modifications on the antenna structures. Several techniques are proposed to design UWB antennas with 
frequency stop or frequency notch characteristics. Depending on the application and the nature and bandwidth of the rejection band, researchers developed novel antennas with an integrated filtering mechanism that provides the desired response. Several antenna designs are reported which provide frequency notch response. Some common techniques [81] used to obtain frequency notches are

- Modifications on the radiator.

- Modifications on the ground plane or signal line.

- Integrated filter techniques.

- Metamaterial-inspired resonators.

Modifications on the radiator and ground planes in the form of slots, stubs, and slits are the most common techniques to achieve frequency notches in a UWB-printed antenna. The literature proposes many configurations using monopole antennas of the planar type, which have a modified radiator characteristic. These configurations have been used as a common practice to alter the current path in printed antennas, which affects the antenna's input impedance. The aforementioned different geometrical structures with varying sizes yielded different notching results by changing the current distribution on the radiator of a UWB antenna.

In [82], a CPW-fed rectangular antenna with a T-shape stub and rectangular slot is proposed. The proposed design gives a notch between 5-6 GHz. An ultrawideband notch antenna with a single parasitic strip is proposed in [83]. Notching is achieved by utilizing an Elliptic slot with three steps, attaching a parasitic strip to the lower end of the antenna, and varying its length. It shows a notched band between 5.1-5.8 GHz.

A monopole antenna with a C-shape slot on a patch in [84] causes a single notch in UWB operating band. Slotted radiating surfaces like T-shaped slot [85], octagonal slot [86], two arc-shaped slots [87], Tapered slot [88], and U-shaped slot [89] are used for rejecting undesired bands from the UWB spectrum. Different geometrical shapes and sizes with slots like fractal geometry in the hexagonal monopole with Y-shape slot [90], Koch Snowflake iterative design with Snowflake slot [91], Fractal Koch structure [92] with T-shaped stub, and Fractal slot [93], two elliptical patches on a hexagonal radiating patch with two C-shape slots [94] are utilized to reject the undesired frequency bands. A tripleband UWB notch antenna is proposed in [95] by using decoupling structure, multi-slit, and multi-slot concepts.

Modifications on the ground plane or signal line were also used to obtain notches in the operating frequency band of the UWB antennas. A UWB notch antenna using open-ended slot is proposed in [96]. A staircase shape monopole UWB notch antenna is proposed in [97]. Wide bandwidth and notching are achieved by utilizing a half-bowtie radiating element, a U-shaped staircase slot, and a modified ground. An antenna with one band-notch has been proposed in [98] and [99]. In [99], the antenna has an arc-edged patch with a partially modified ground plane. The microstrip-fed dipole of semi-elliptical shape antenna [100], CPW and ACS-fed monopole with DGS [101], CPW-fed L-slot microstrip antenna [102], offset microstrip-fed UWB antenna with L-shaped slits on the ground [103], and slots in the shape of arcs in monopoles [104] have been utilized to reject the undesired frequency bands. A three-band notch antenna has been proposed in [105]. In this design, two bevels in the patch, two bevels in the ground are used to get wide bandwidth. The usage of two round slots of half-wavelength along with two slots of $C$ shape in the ground plane gives a notch at the desired frequency.

Several band rejection techniques like asymmetrical resonator in the feed line, parasitic strip on the radiator, inverted-L slot on the ground plane [106], tapered edge on the ground plane and rectangular slots on patch [107], Circular-stub-based multimode-resonator UWB filter [108], resonant parallel strip (RPS) [109], four stubs and stepped slot in the ground plane [110], H-slot patch for radiation and a slot of $U$ shape for feeding [111], slot resonators on Y-shaped monopole radiator [112], parasitic resonator [113], meander line resonator with open ended stub loading [114], inverted U-shaped and I-shaped slots each of half guided wavelength on radiator [115], EBG structure [89,116] Notch filter in the patch [117], 
parasitic loading and slot techniques [118], DGS and orthogonal polarization [119], inverted L-shaped stub resonator [120], and a stub with an open end with a meandered resonator along with defective ground structure [121] are reported in the literature to receive band notch characteristics.

Recently, metamaterial (MTM)-inspired resonators have been utilized to achieve notching in UWB operating band. Due to the advancement in consumer electronics, the antenna on demand must have high channel capacity, gain, bandwidth, and compact size. Many techniques have been proposed to improve antennas' performance over the last decade. One of such techniques is metamaterials. Due to their superior properties compared to natural materials, Metamaterials have achieved enormous attention from researchers [122].

MTM inspired antenna is designed using the unit cell structures into the ground plane or radiator. This unit cell structure acts as a resonant structure in the antenna [123]. A circular split-ring resonator (C-SRR), Square split-ring resonator (S-SRR), Hexagonal splitring resonator (H-SRR), and Rotational circular split-ring resonator (RC-SRR) are the most common SRR configurations used for frequency notch applications. Many metamaterialinspired resonators like C-SRR in the signal line [124], Complementary Split Ring Resonator slot [125], Symmetrical Split Ring Resonator [126], the combination of complementary split ring resonators (CSRR), split ring resonators (SRR) and DGS [127], SRR [128], open loop resonators [129], elliptic split ring resonator (ESRR), and a round split ring resonator (RSRR) along with U-shaped parasitic strips near the signal line [130] are reported in the literature to receive band notch characteristics.

Based on the above techniques, various metamaterial-based UWB notch antennas are designed [131-139]. In the paper [131], UWB antenna is designed using double-slotted ring resonators, circular (C-SRR) and square (S-SRR). It has impedance bandwidth from 3.5-9 GHz and a gain of $5 \mathrm{dBi}$. It shows multiple band frequencies rejection and stable radiation patterns. In the paper [132], a UWB monopole notch antenna is designed using SRR on the ground plane. It has an operating band from 3.1-10.6 GHz It has a notched band from 5-6 GHz and functions for WLAN. In [133], authors have proposed a dual-band UWB notch antenna using a CSRR on the patch and the SRR on the ground plane. It is useful for WiFi 6E and 5G communication. In [134], a UWB antenna is proposed using an annular SRR slot and a rectangular SRR slot to achieve dual notched band characteristics. In [135], a UWB notch antenna was designed for 5G, WLAN, and Satellite downlink bands applications. The authors use EBG structures to notch 5G and WLAN bands and 2 SRR to notch Satellite downlink bands. A triple-band planer antenna using metamaterials has been proposed in [136]. This design uses the annular defected ground to get wide bandwidth. The multi resonant metamaterial cell usage gives a triple band of 2.38-2.48, 3.37-3.79, and 4.36-6.06 GHz. A single-notch UWB MIMO antenna using a parasitic decoupler has been proposed in [137]. This design uses a parasitic decoupler to improve the isolation between antenna elements. The U-shape slot usage in the radiator gives a notched band of 4.2-5.8 GHz. A triple band-notched UWB antenna has been proposed in [138]. This design uses a SRR in the ground to notch WiMAX (3.3-3.8 GHz) and WLAN (5.15-5.825 GHz). The U-shape slot usage in the feed line gives a notched band of X-band $(7.25-8.395 \mathrm{GHz})$. In [139], a UWB notch antenna was designed for rejection of the WLAN band. The authors use slotted complementary SRRs structures in a circular patch on a partial ground plane to notch the WLAN band of $5.5 \mathrm{GHz}$.

Table 3 tabulates the aforementioned sharp band rejection techniques and their key design features and radiation characteristics to avoid overlapping the UWB with the interference bands. 
Table 3. The emergence of design of UWB notch antenna.

\begin{tabular}{|c|c|c|c|c|c|c|c|c|}
\hline Ref. No. & $\begin{array}{c}\text { Size } \\
\left(\mathrm{mm}^{2}\right)\end{array}$ & Antenna DESIGN & $\begin{array}{l}\text { Gain } \\
\text { (dBi) }\end{array}$ & Efficiency & Methodology & Notching Structure & Advantage/Disadvantage & $\begin{array}{c}\text { Notch Frequency } \\
\text { Range (GHz) }\end{array}$ \\
\hline [82] & $35 \times 30$ & - & 7 & - & $\begin{array}{l}\text { The rectangular } \\
\text { aperture is designed by } \\
\text { minimizing the } \\
\text { aperture area and } \\
\text { causing impedance } \\
\text { matching. }\end{array}$ & $\begin{array}{l}\text { Rectangular slot with } \mathrm{T} \\
\text { stub feed }\end{array}$ & $\begin{array}{c}\text { Advantage: } \\
\text { Good radiation pattern. } \\
\text { Disadvantage: Gain } \\
\text { decrease in second } \\
\text { resonant mode due to } \\
\text { cross-polarization } \\
\text { decoupling }\end{array}$ & $5-6$ \\
\hline [83] & $20 \times 20$ & - & 3.5 & - & $\begin{array}{l}\text { A parasitic strip to the } \\
\text { lower end of the } \\
\text { antenna with varied } \\
\text { lengths causes } \\
\text { notching. }\end{array}$ & $\begin{array}{l}\text { Elliptic slot with three } \\
\text { steps }\end{array}$ & $\begin{array}{c}\text { Advantage: } \\
\text { Good radiation } \\
\text { characteristics and } \\
\text { impedance matching. } \\
\text { Disadvantage: } \\
\text { Poor cross polarization } \\
\end{array}$ & $5.1-5.8$ \\
\hline [85] & $30 \times 30$ & - & 7 & - & $\begin{array}{l}\text { The concentration of } \\
\text { current on the } \\
\text { conductor's outer edge } \\
\text { and the fork-shaped } \\
\text { strip causes band } \\
\text { rejection in selected } \\
\text { bands }\end{array}$ & $\begin{array}{l}\text { T shaped slot in a } \\
\text { fork-shaped strip }\end{array}$ & $\begin{array}{c}\text { Advantage: } \\
\text { Stable radiation pattern. } \\
\text { Disadvantage: } \\
\text { There is distortion in } \\
\text { the incoming signal in } \\
\text { the frequency band of } \\
\text { interest. }\end{array}$ & $5.1-5.8$ \\
\hline [86] & $29 \times 30$ & - & 4 & - & $\begin{array}{l}\text { Square ring resonator is } \\
\text { used to achieve } \\
\text { notching. }\end{array}$ & $\begin{array}{l}\text { Octagonal slot with a } \\
\text { rectangular stub for } \\
\text { tuning }\end{array}$ & $\begin{array}{c}\text { Advantage: } \\
\text { Sharp frequency } \\
\text { notch. } \\
\text { Disadvantage: } \\
\text { Radiation pattern can } \\
\text { be improved. }\end{array}$ & $5.2-5.9$ \\
\hline [87] & $26 \times 26$ & 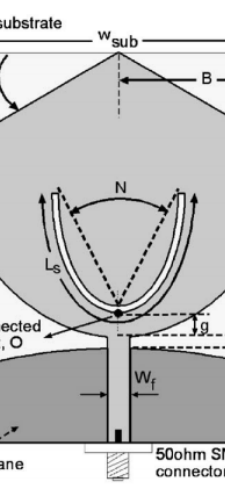 & 5 & - & $\begin{array}{l}\text { A semi-elliptical patch } \\
\text { with dielectric material } \\
\text { on both sides of the } \\
\text { patth increases the } \\
\text { effective patch, thereby } \\
\text { increasing the } \\
\text { bandwidth. }\end{array}$ & $\begin{array}{l}\text { Two arc-shaped slots } \\
\text { which are connected }\end{array}$ & $\begin{array}{l}\text { Advantage: } \\
\text { Good radiation pattern } \\
\text { and good gain. } \\
\text { Disadvantage: } \\
\text { Complex design }\end{array}$ & $5.1-5.9$ \\
\hline
\end{tabular}


Table 3. Cont.

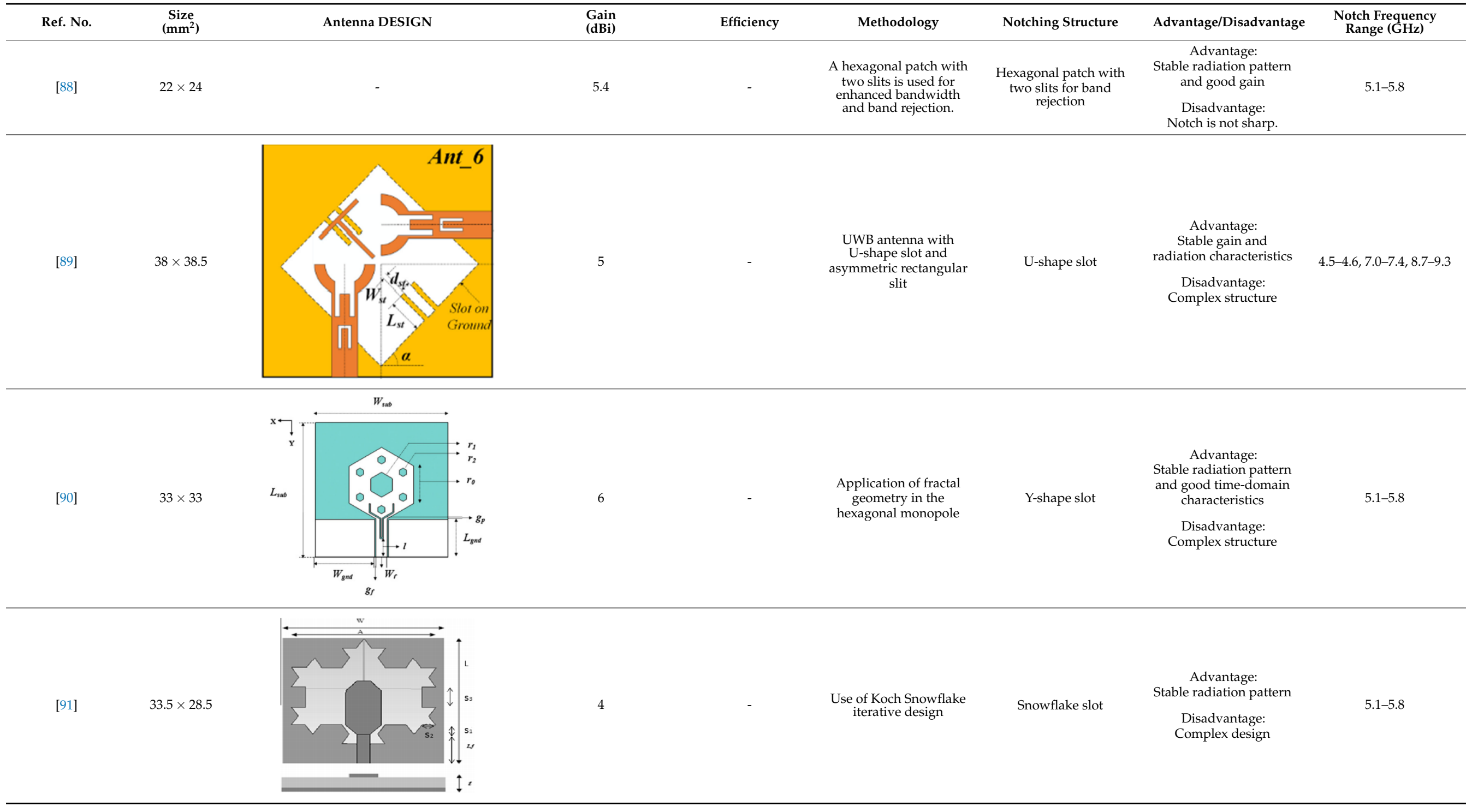


Table 3. Cont.

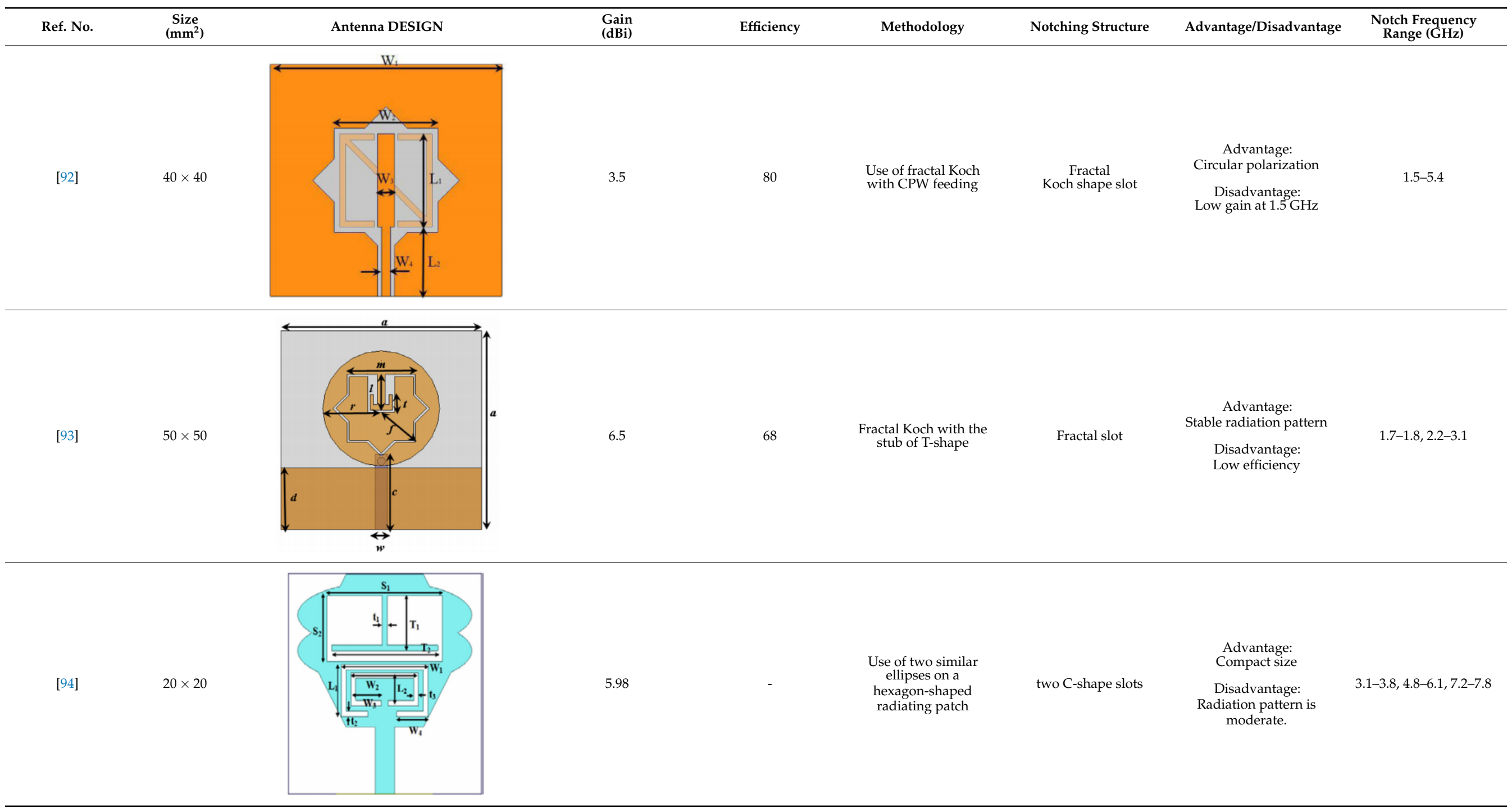


Table 3. Cont.

\begin{tabular}{|c|c|c|c|c|c|c|c|c|}
\hline Ref. No. & $\begin{array}{c}\text { Size } \\
\left(\mathrm{mm}^{2}\right)\end{array}$ & Antenna DESIGN & $\begin{array}{l}\text { Gain } \\
\text { (dBi) }\end{array}$ & Efficiency & Methodology & Notching Structure & Advantage/Disadvantage & $\begin{array}{l}\text { Notch Frequency } \\
\text { Range (GHz) }\end{array}$ \\
\hline [95] & $39 \times 39$ & & 3.2 & - & $\begin{array}{l}\text { Use of decoupling } \\
\text { structure, multi-slit, } \\
\text { and multi-slot concepts }\end{array}$ & Multi-slot & $\begin{array}{c}\text { Advantage: } \\
\text { Low mutual coupling ( } \\
<-22 \mathrm{~dB}) \\
\text { Low ECC } \\
\text { Disadvantage: } \\
\text { Gain can be improved. }\end{array}$ & $3.2-3.7,5.0-5.9,7.0-7.9$ \\
\hline [96] & $19 \times 30$ & & 2.91 & $70-90$ & $\begin{array}{l}\text { UWB antenna with } \\
\text { T-shaped stub and } \\
\text { open-ended slot }\end{array}$ & Open-ended slot & $\begin{array}{c} \\
\\
\text { Advantage: } \\
\text { Stable radiation pattern } \\
\text { and low ECC } \\
\text { Disadvantage: } \\
\text { Low gain }\end{array}$ & $4.3-5.9,6.5-7.4$ \\
\hline [103] & $38 \times 38.5$ & - & 3.6 & 75 & $\begin{array}{l}\text { The offset } \\
\text { microstrip-fed slot } \\
\text { antenna }\end{array}$ & Rhombic slot & $\begin{array}{c}\text { Advantage: } \\
\text { Sharp notch, low } \\
\text { mutual coupling, and } \\
\text { low envelope } \\
\text { correlation coefficient } \\
\text { Disadvantage: } \\
\text { Low efficiency }\end{array}$ & $5.0-5.9$ \\
\hline [104] & $64 \times 64$ & - & 3 & 75 & $\begin{array}{l}\text { Use of orthogonal pairs } \\
\text { of differential-fed } \\
\text { elements and the } \\
\text { irregular octagonal } \\
\text { ground plane }\end{array}$ & $\begin{array}{l}\text { Octagonal- } \\
\text { shaped slot }\end{array}$ & $\begin{array}{c}\text { Advantage: } \\
\text { Wide bandwidth and } \\
\text { low cross-polarization } \\
\text { Disadvantage: } \\
\text { Measured efficiency is } \\
\text { lower than simulated } \\
\text { efficiency }\end{array}$ & $5-6.1$ \\
\hline
\end{tabular}


Table 3. Cont.

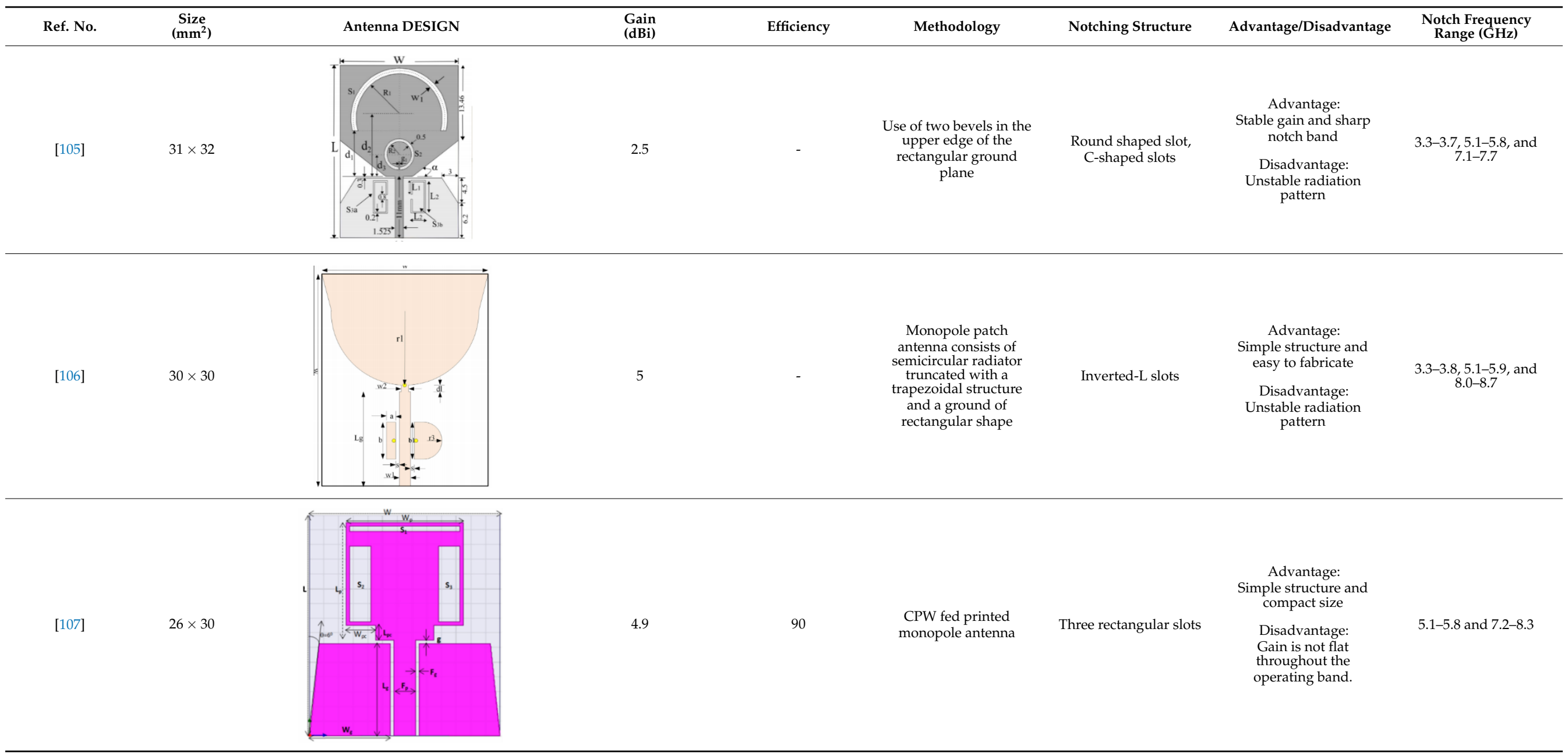


Table 3. Cont.

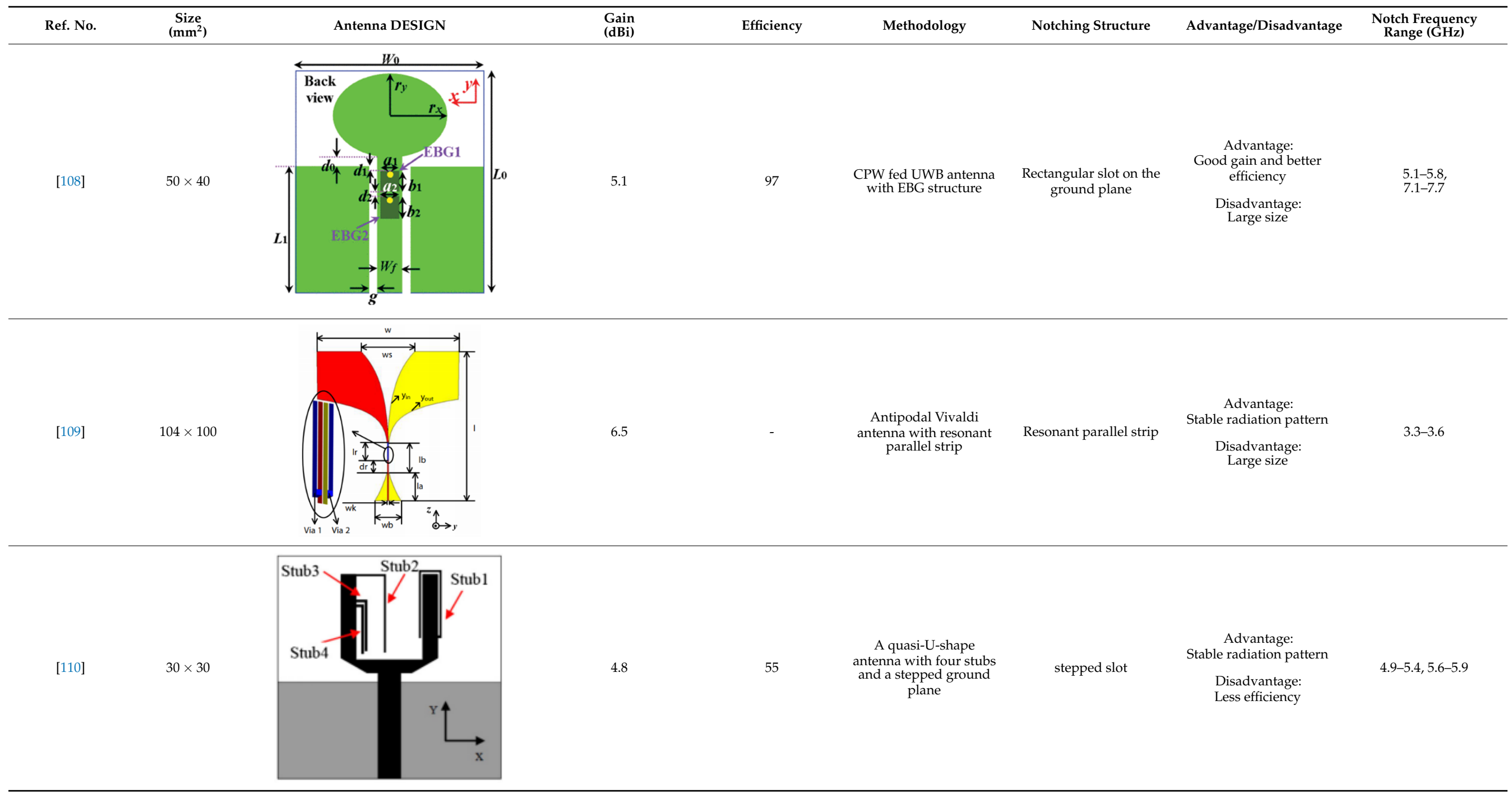


Table 3. Cont.

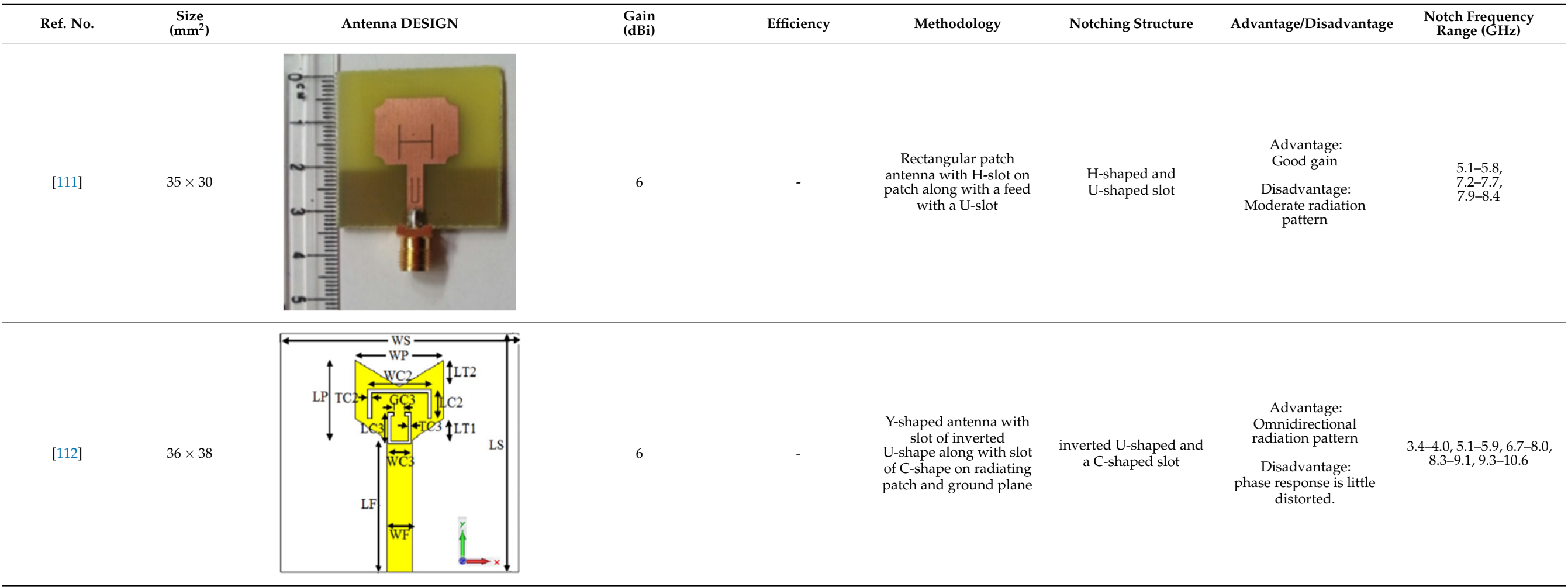


Table 3. Cont.

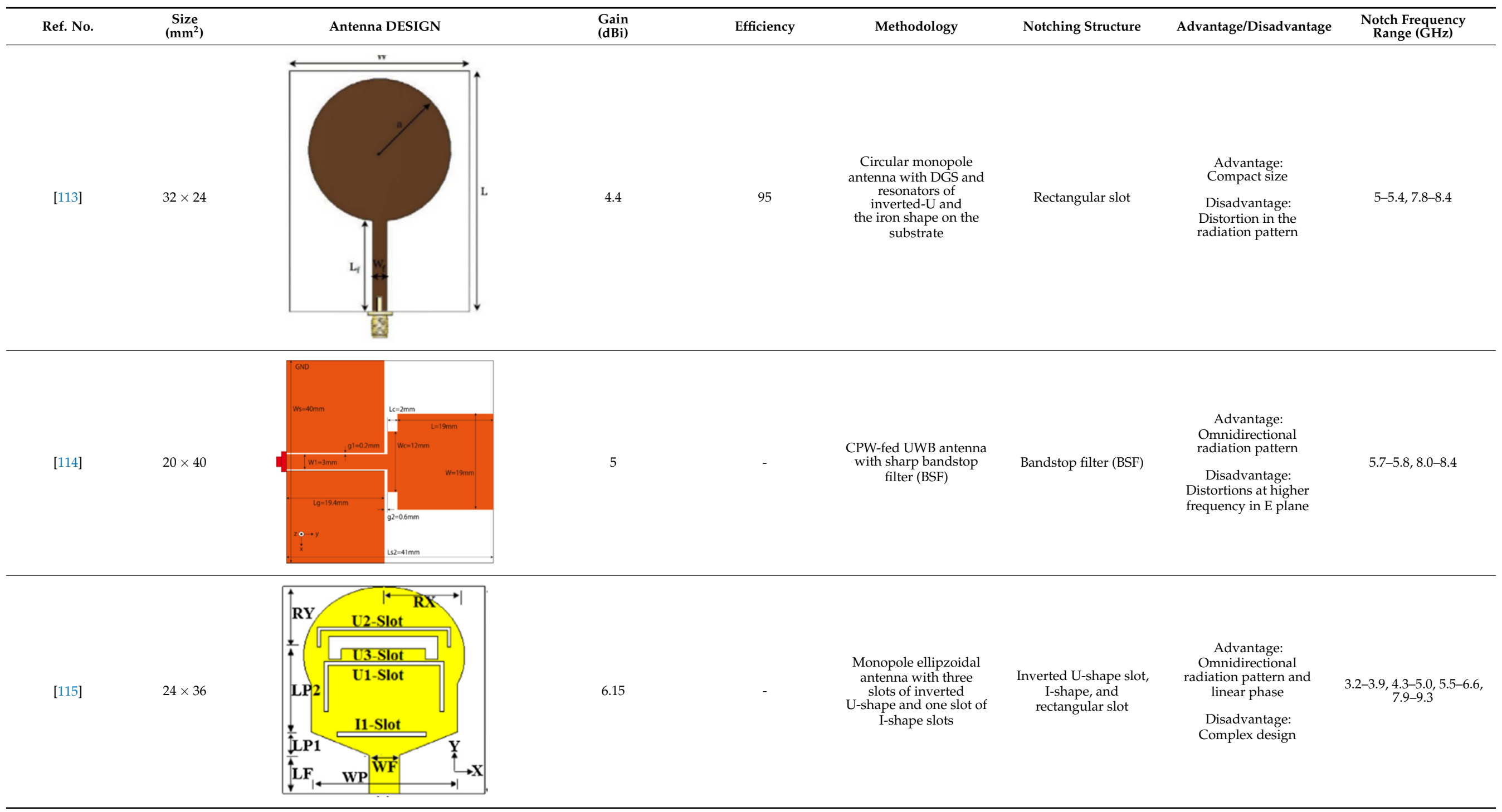


Table 3. Cont.

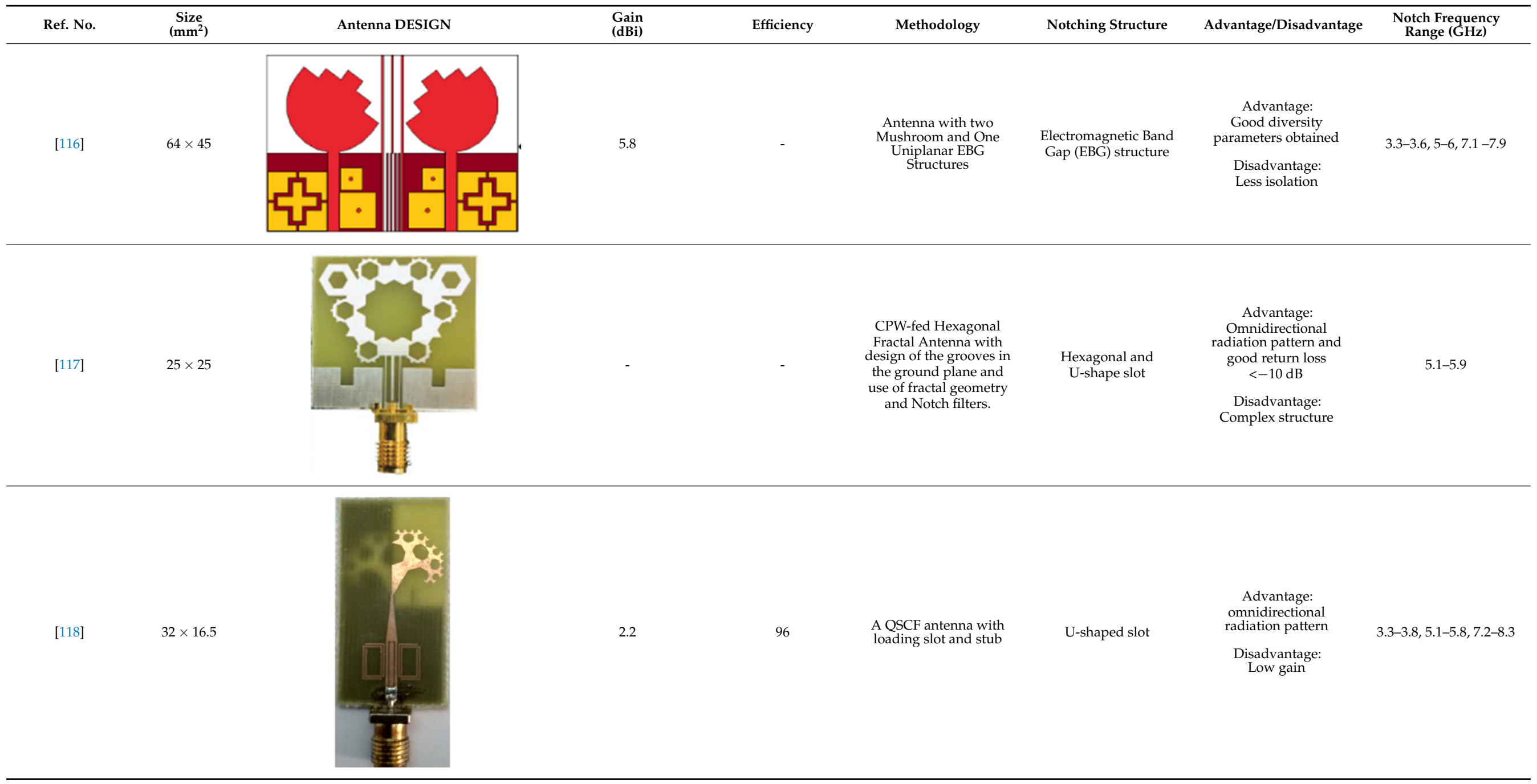


Table 3. Cont.

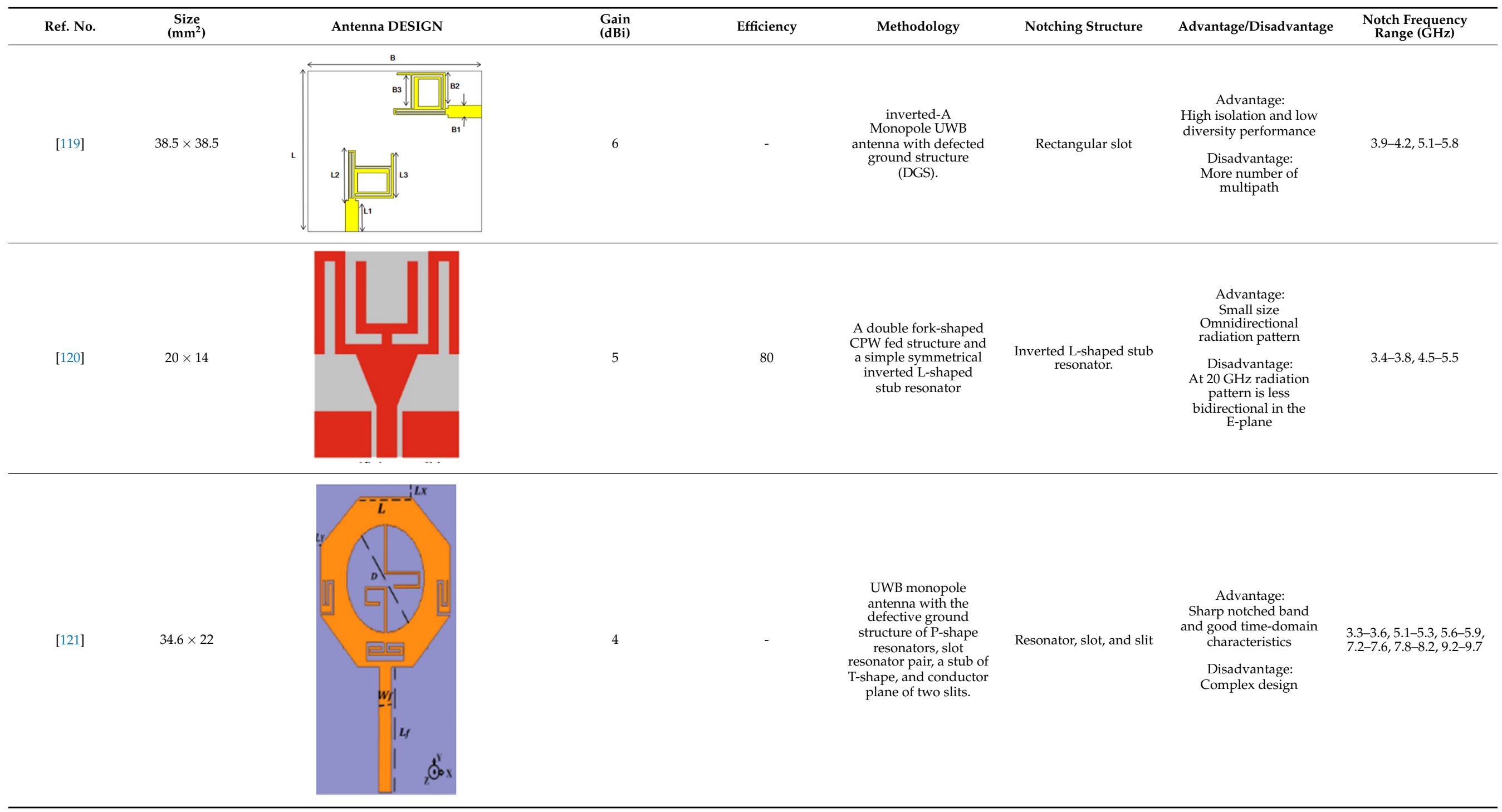


Table 3. Cont.

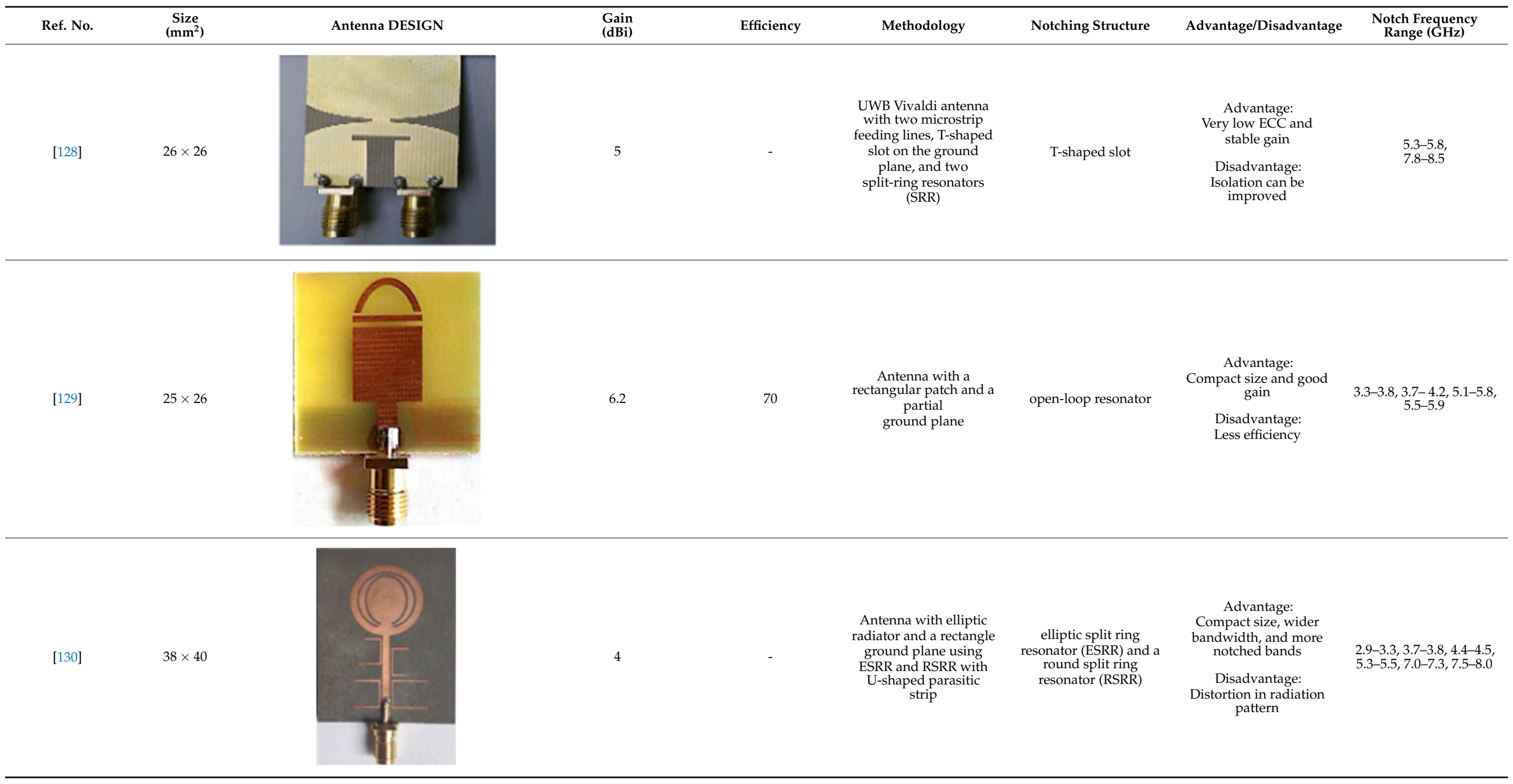


Table 3. Cont.

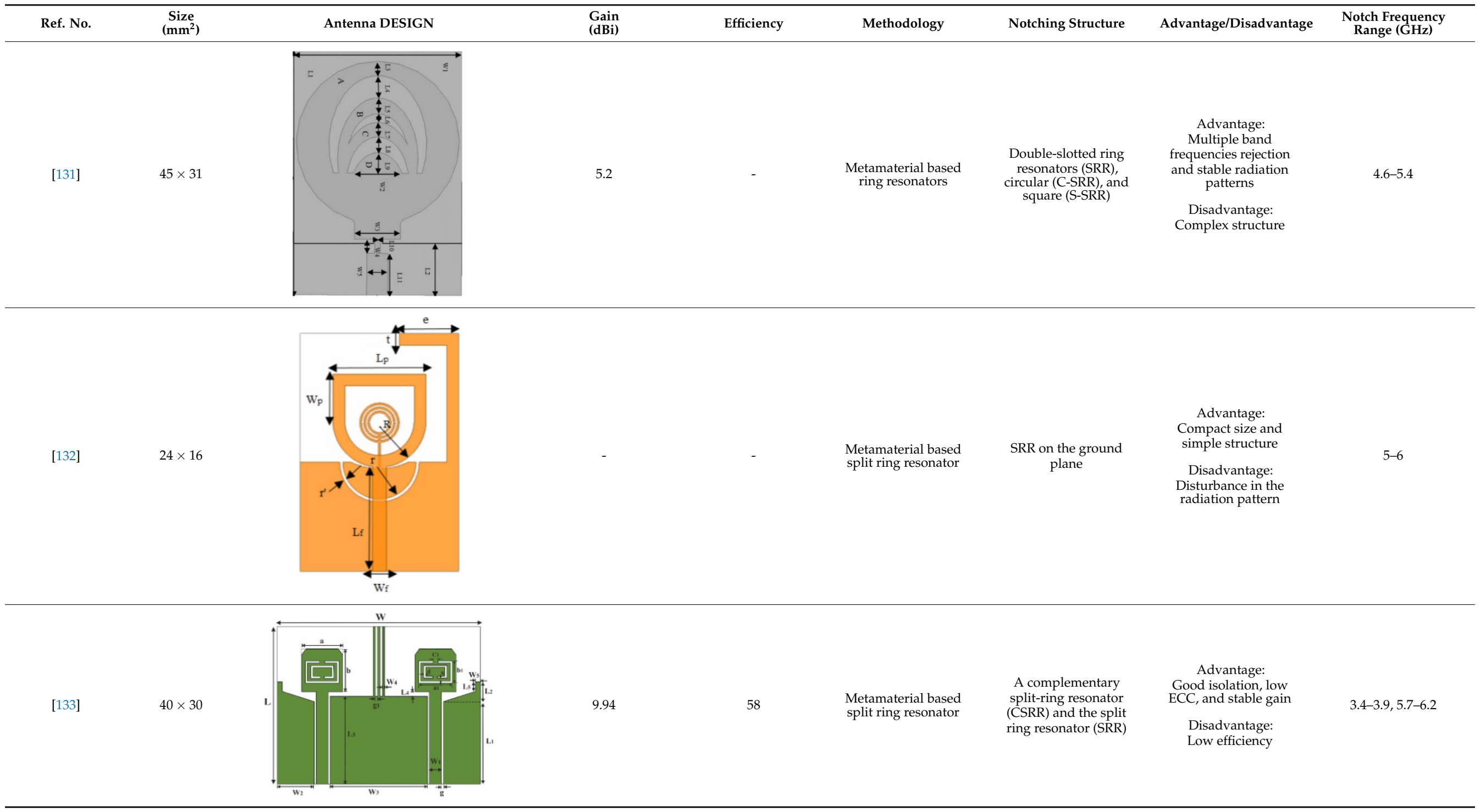


Table 3. Cont.

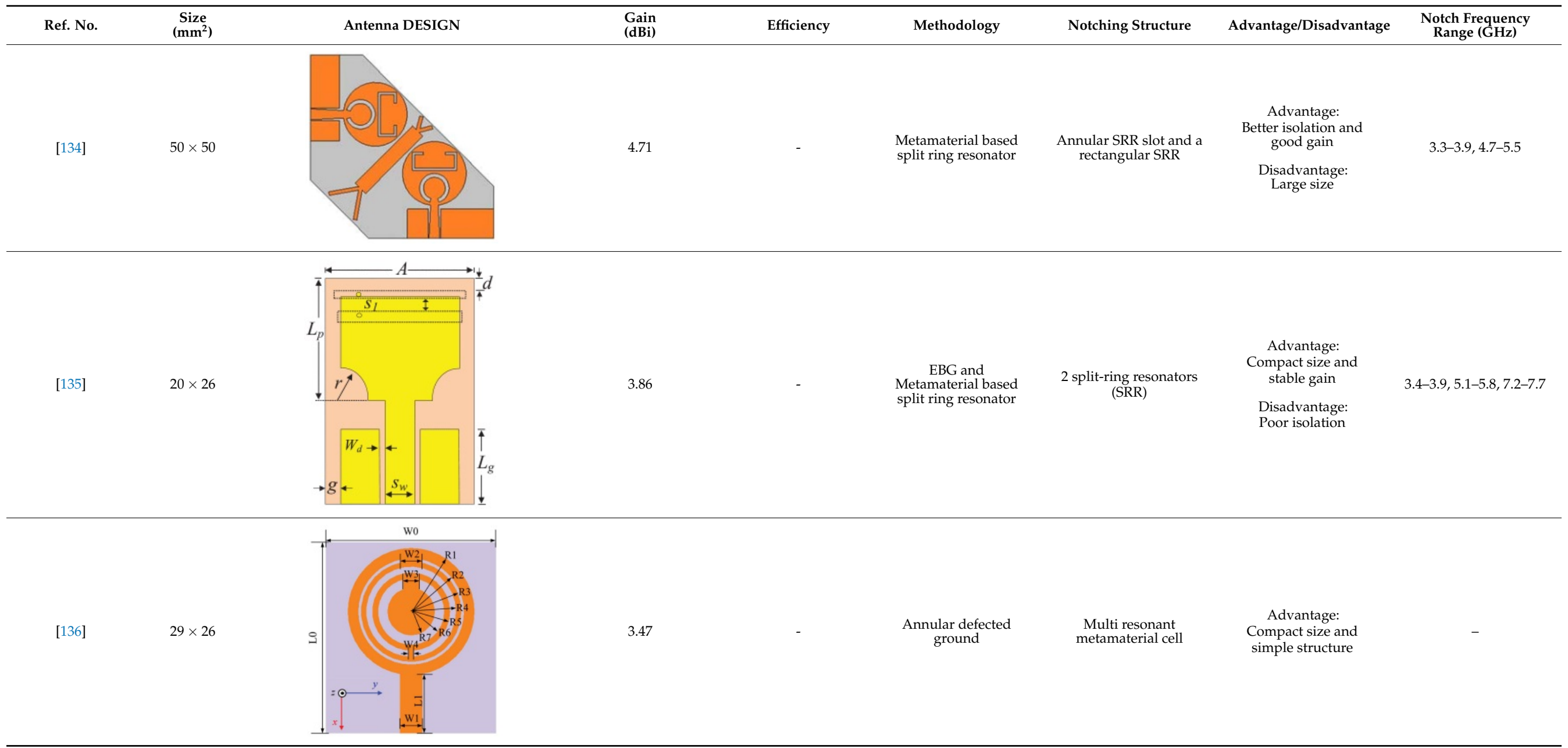


Table 3. Cont.

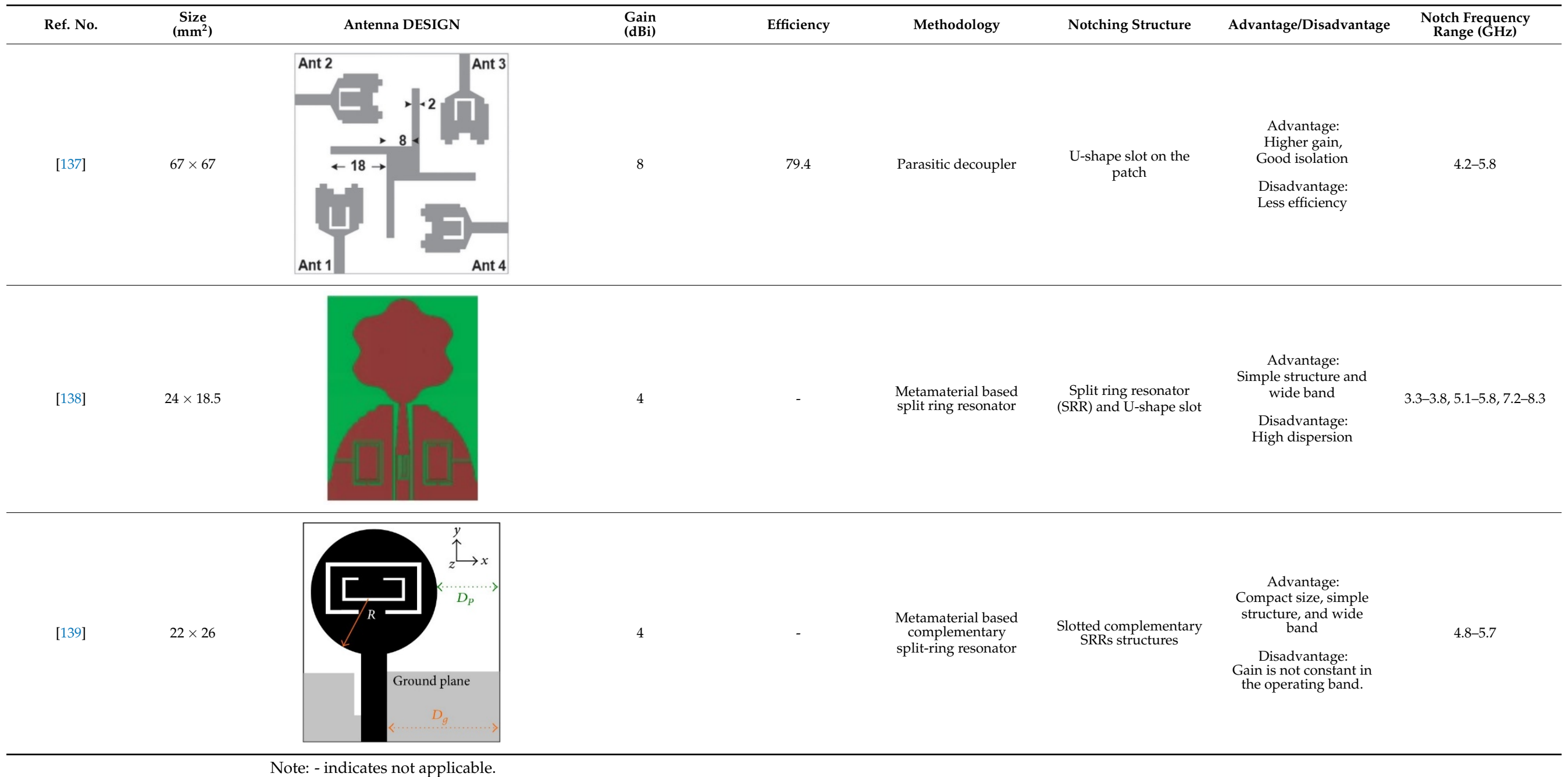




\section{Frequency Reconfigurable UWB Notch Antenna}

The previous two sections have showcased the evolution of UWB antennas and UWB notch antenna and their design methodology. With the emergence of reconfigurable circuits, UWB technology also adapted the concept of frequency reconfiguration and several frequency-reconfigurable UWB notch antennas have been designed.

\subsection{Principle of Antenna Reconfiguration}

Over the years, antennas can be divided into broad categories, which include wire antennas, waveguide antennas, log-periodic antennas, microstrip antennas, reflector antennas, and aperture antennas. According to the need of the design, these basic antenna structures are used to develop new structures to suit the needs. Changing the structure of an antenna to suit the need of the application is an engineering design problem. Here is where the concept of reconfiguration has been explored. If antennas are designed to be reconfigurable, then significant changes in the physical design need not be made to accommodate changes in the radiation pattern output that may be required [140].

The ability to change an antenna's fundamental operating characteristics based on either electrical or mechanical means is termed reconfiguration. Ideally, reconfigurable antennas can alter their frequency of operation, impedance bandwidths, polarization, and other radiation parameters to accommodate changes in the output requirements [141]. Despite the huge cost that reconfigurable antennas pose, the concept of reconfigurability has gained momentum due to its wide range of applications in single element and array antenna scenarios. Small portable devices which use UWB range of frequencies may have to operate in harsh or unpredictable environments with weak signal strength in specific ranges of frequencies. In such cases, the reconfigurable antennas prove their mettle by switching from one frequency to another based on the conditions of operation. Reconfigurability requires complex control and feedback circuitry along with complicated fabrication procedures. Reconfiguration can be made possible in frequency, gain, or polarization. The main focus is to present frequency reconfigurable UWB notch antennas as they are the most widely used.

\subsection{Frequency Reconfigurable Antennas}

Frequency reconfigurable antennas have varied operations at different frequencies. A number of single frequency antennas can be replaced with a single reconfigurable antenna. Frequency reconfigurability is achieved using tuning mechanism, notching, or using switches [142]. Reconfigurable antennas can be integrated with electronic switches such as a PIN or Varactor diodes or switching through RF switches. Tunable materials with changing permittivity and varying height of the substrate can also be used for reconfiguration. PIN diodes provide the advantage of a low insertion loss, a good switching speed with a small size, and cheap cost. Lumped components such as PIN diodes, metal-oxide semiconductor field-effect transistors (MOSFETs), and RF MEMS (radio frequency microelectromechanical systems) switches can be used for performing switching. MEMS switches outperform PIN diodes and MOSFETs in terms of providing better isolation and consuming lower power. Tunable materials such as liquid crystals and ferrites can be used for reconfiguration as their dielectric constants can be changed with a change in voltage levels. This accounts for these materials changing their properties into other materials with varied permittivity and permeability [143].

In [144], electronic switches are placed on the slot of complementary split ring resonators (CSRRs), causing one to activate at a particular instant of time, causing band notching in a specific range of frequencies. On switching, the notch is created in another set of frequencies. In a second design, the notching appears when the switch is turned on and disappears when the switch is turned off. The authors of [145] use PIN diode switches to reject frequencies belonging to the Bluetooth and wireless LAN bands in UWB operation. Like [145], in [146], the rejection of WiMAX and WLAN bands is performed using PIN diodes. In [147], reconfiguration of the UWB antenna is achieved using a band stop filter. 
The filters are proposed using SRRs and CSSRs. Notches in four bands are obtained in [148] by shorting a slot of U-shape. The corresponding reconfiguration is achieved using an L-shaped slot for a wider band of resonance. In [149], two reconfigurable dielectric UWB antennas have been presented. Both these antennas achieve reconfigurability through rotation of the Dielectric Resonator (DR) with a stepper motor connected to it for activation.

The authors of [150] have presented the usage of two PIN diodes in a resonance cell to achieve reconfiguration of the UWB antenna by regulation of the capacitance using a varactor diode in the middle of the resonance cell. In [151], the band stop behavior is reconfigured to a bandpass behavior of the UWB antenna using PIN diodes with the CPW loaded S-SRRs. The authors of [152] present the design of a reconfigurable UWB antenna using stepped slots and five PIN diodes for switching in different stages.

The authors of [153] have presented a complex UWB reconfigurable antenna design that comprises three slots in the ground plane with parasitic strips on the feed resulting in seven states of operation. Five PIN diodes have been used to perform the switching between the seven stages of operation. References [154,155] have presented a G-shaped monopole UWB reconfigurable antenna with a PIN diode for switching and a cup-shaped UWB reconfigurable antenna with rejection in three bands using stubs and slots with three PIN diodes for switching, respectively. In [156], the authors have proposed the usage of hexagonal SRR metamaterial cells and switches for reconfiguration. In [157], the authors present a design of a band-notched UWB reconfigurable antenna which is achieved using varactor diodes placed between the split ring slots of the CSSRs used for notching. Finally, in [158], reconfiguration is achieved in the UWB notched antenna using biasing circuits of capacitors and inductors and PIN diodes for switching. Table 4 highlights the key features of the reconfigurable antennas presented above, along with the reasons for their reconfigurability.

The above section presented some prominent reconfigurable UWB notch antennas until 2020. This section has showcased that with the advent and popularity of reconfiguration, several antennas have been designed to suit the needs of band notching in the UWB range of frequencies. Despite the tradeoff of high complexity and preliminary cost of these designs, frequency reconfigurable antennas are gaining momentum due to the lasting feature of switching from one frequency to another, thereby reducing the need for multiple antennas to achieve the same purpose. 
Table 4. The emergence of design of frequency reconfigurable UWB notch antenna.

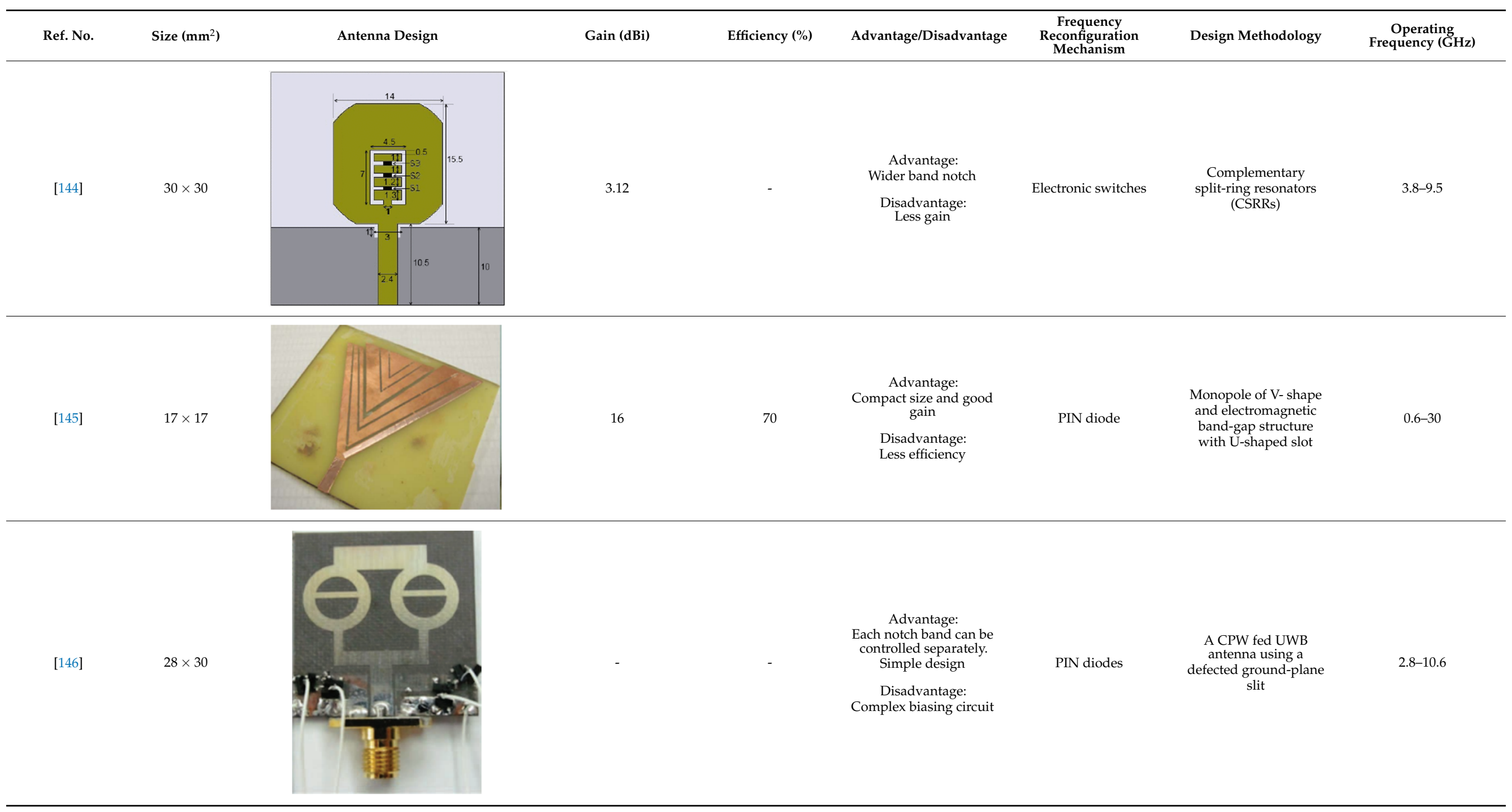


Table 4. Cont.

\begin{tabular}{|c|c|c|c|c|c|c|c|c|}
\hline Ref. No. & Size $\left(\mathrm{mm}^{2}\right)$ & Antenna Design & Gain (dBi) & Efficiency $(\%)$ & Advantage/Disadvantage & $\begin{array}{c}\text { Frequency } \\
\text { Reconfiguration } \\
\text { Mechanism }\end{array}$ & Design Methodology & $\begin{array}{c}\text { Operating Frequency } \\
\text { (GHz) }\end{array}$ \\
\hline [147] & $25 \times 20$ & & 5 & - & $\begin{array}{c}\text { Advantage: } \\
\text { More unlicensed users } \\
\text { can operate since it } \\
\text { dynamically rejects a } \\
\text { band. } \\
\text { Disadvantage: } \\
\text { The efficiency of the } \\
\text { proposed antenna } \\
\text { needs to be further } \\
\text { explored. }\end{array}$ & RF switches & $\begin{array}{l}\text { Filter antennas using } \\
\text { CSRRs and SRRs }\end{array}$ & $2.1-7.5$ \\
\hline & & & 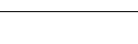 & & 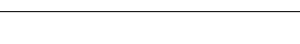 & & & \\
\hline [148] & $30 \times 31$ & & 4.5 & - & $\begin{array}{c}\text { Advantage: } \\
\text { Simple structure and } \\
\text { constant group delay } \\
\text { Disadvantage: } \\
\text { Distortion during pulse } \\
\text { transmission }\end{array}$ & RF switches & $\begin{array}{l}\text { Shorting the U-shaped } \\
\text { slots on the patch }\end{array}$ & $2.4-10.8$ \\
\hline
\end{tabular}


Table 4. Cont.

\begin{tabular}{|c|c|c|c|c|c|c|c|c|}
\hline Ref. No. & Size $\left(\mathrm{mm}^{2}\right)$ & Antenna Design & Gain (dBi) & Efficiency $(\%)$ & Advantage/Disadvantage & $\begin{array}{l}\text { Frequency } \\
\text { Reconfiguration } \\
\text { Mechanism }\end{array}$ & Design Methodology & $\begin{array}{c}\text { Operating Frequency } \\
\text { (GHz) }\end{array}$ \\
\hline [149] & $50 \times 44$ & & 4 & - & $\begin{array}{c}\text { Advantage: } \\
\text { Shows reconfiguration } \\
\text { characteristics for } \\
\text { microwave and WiMax } \\
\text { applications } \\
\text { Disadvantage: } \\
\text { The antenna gain } \\
\text { variations are not } \\
\text { uniform. }\end{array}$ & $\begin{array}{l}\text { Rotation DR with } \\
\text { stepper motor }\end{array}$ & $\begin{array}{l}\text { Rectangular split-ring } \\
\text { slot }\end{array}$ & $3.2-5.1$ \\
\hline [150] & $30 \times 30$ & $\frac{2}{2} \mathrm{i} \cdot \mathrm{E}$ & - & - & $\begin{array}{l}\text { Advantage: } \\
\text { It can mitigate UWB } \\
\text { interference and the } \\
\text { notch } \\
\text { has narrowband } \\
\text { functionality. } \\
\text { Disadvantage: } \\
\text { The biasing circuit } \\
\text { utilized to obtain } \\
\text { reconfiguration affects } \\
\text { the gain and radiation } \\
\text { pattern of the antenna } \\
\text { drastically. }\end{array}$ & $\begin{array}{l}\text { PIN and varactor } \\
\text { diodes }\end{array}$ & Switchable slots & $3.1-10.6$ \\
\hline
\end{tabular}


Table 4. Cont.

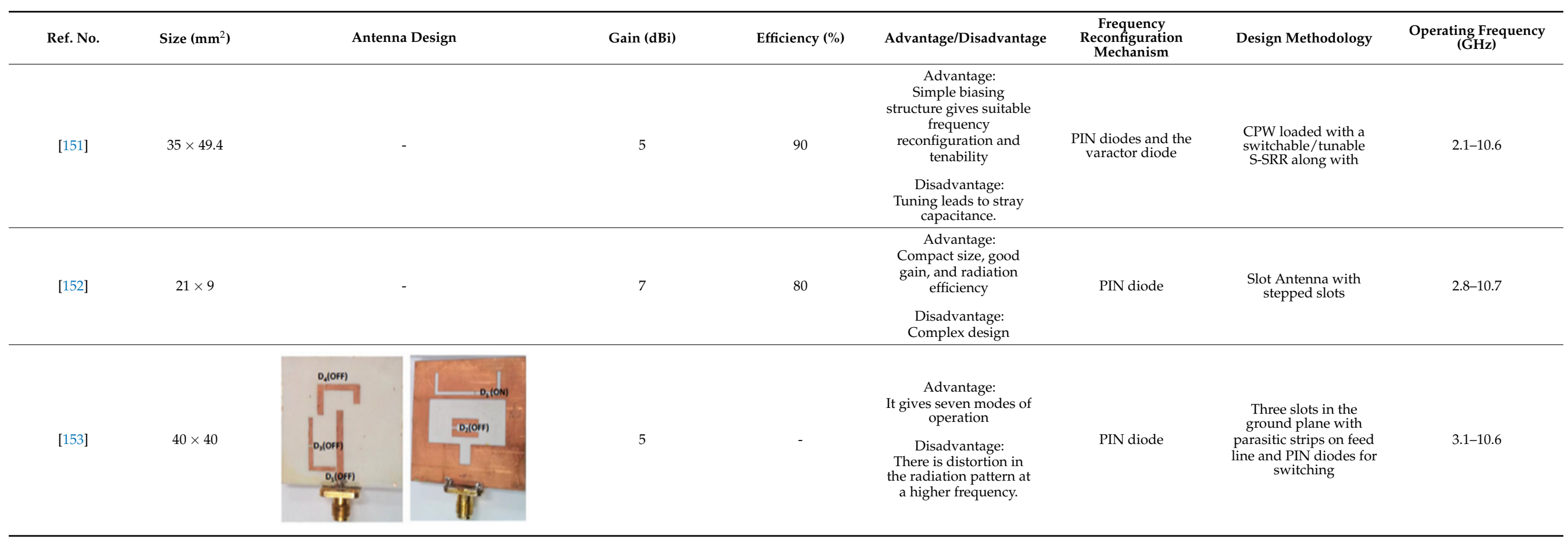


Table 4. Cont.

\begin{tabular}{|c|c|c|c|c|c|c|c|c|}
\hline Ref. No. & Size $\left(\mathrm{mm}^{2}\right)$ & Antenna Design & Gain (dBi) & Efficiency (\%) & Advantage/Disadvantage & $\begin{array}{c}\text { Frequency } \\
\text { Reconfiguration } \\
\text { Mechanism }\end{array}$ & Design Methodology & $\underset{\text { (GHz) }}{\text { Operating Frequency }}$ \\
\hline [154] & $8 \times 27.5$ & & 4 & $>70$ & $\begin{array}{c}\text { Advantage: } \\
\text { Compact size, stable } \\
\text { gain and } \\
\text { reconfigurability } \\
\text { Disadvantage: } \\
\text { The proposed antenna } \\
\text { does not show stable } \\
\text { radiations at higher } \\
\text { operating frequencies. }\end{array}$ & PIN diode & $\begin{array}{l}\text { G-shaped monopole } \\
\text { with PIN diode }\end{array}$ & $2.8-12.6$ \\
\hline [155] & $22 \times 28$ & iew & 3 & $80-95$ & $\begin{array}{l}\text { Advantage: } \\
\text { Good radiation } \\
\text { efficiency } \\
\text { Disadvantage: } \\
\text { The biasing circuit } \\
\text { greatly affects the } \\
\text { return loss, gain, and } \\
\text { radiation pattern. }\end{array}$ & PIN diode & $\begin{array}{l}\text { Monopole antenna } \\
\text { with T-shaped slot }\end{array}$ & 3-14 \\
\hline [156] & $30 \times 40$ & (1) (1) & 6 & - & $\begin{array}{c}\text { Advantage: } \\
\text { Filters the frequency } \\
\text { sweep of narrowband } \\
\text { from } 5.7 \mathrm{GHz} \text { to } 8 \mathrm{GHz} \\
\text { Disadvantage: } \\
\text { Complex structure }\end{array}$ & PIN diodes & $\begin{array}{l}\text { Hexagonal SRR } \\
\text { metamaterial cells }\end{array}$ & 2.8-11 \\
\hline
\end{tabular}


Table 4. Cont.

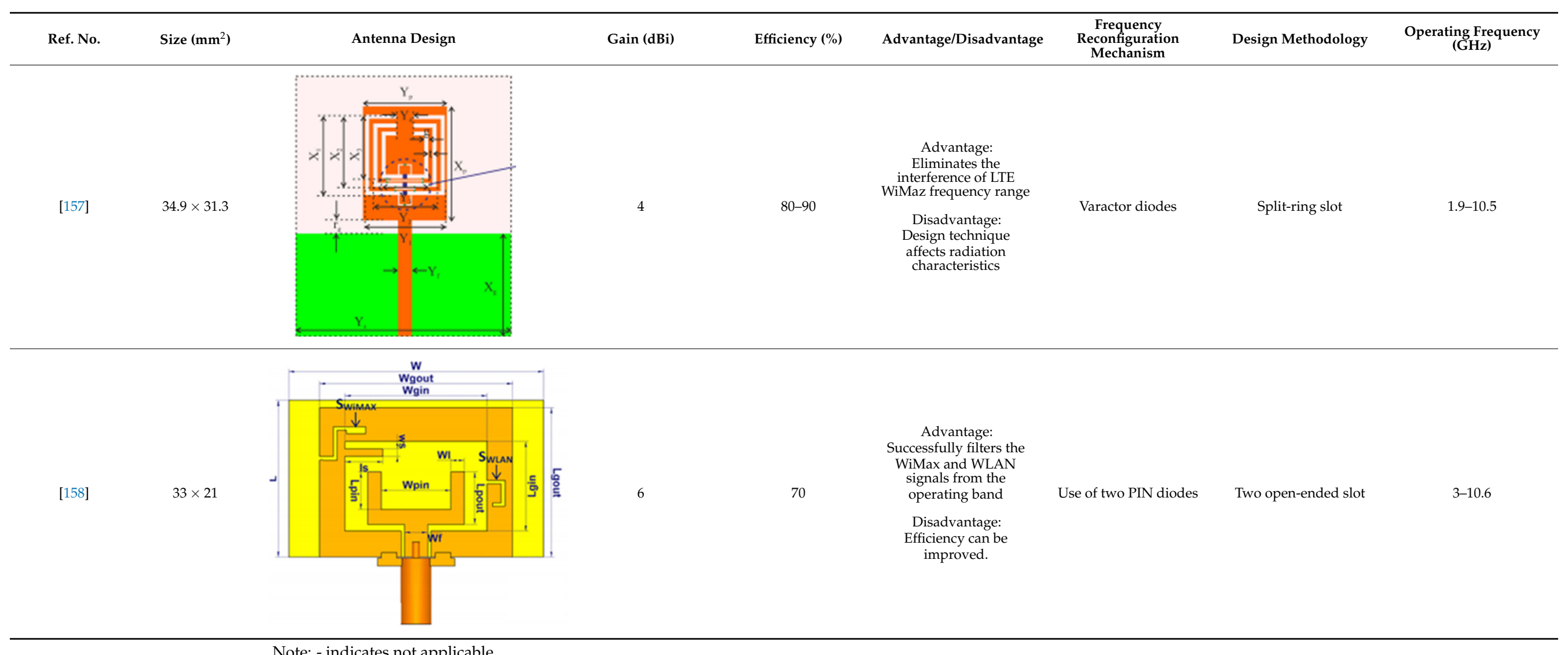




\section{Conclusions}

This article aims to present the trend of growth of UWB antenna technology from 2001 to 2020. The article describes the great potential of UWB technology in communication and the need to develop it further for varied applications. The first section of this article presented the UWB technology antennas with their various applications. It has been clearly observed that UWB technology can cater to several applications, ranging from ground-penetrating radars for disaster management to medical diagnostics and commercial applications such as USB dongles and mobile phones. Section 3 of this article presented the emergence of pure UWB antennas, which radiated in the range of 3.1 to $10.6 \mathrm{GHz}$. These antennas do not have notches in any frequency ranges. Due to the interference caused by the WLAN and WiMAX frequency bands, the concept of notching was introduced in UWB technology. Several UWB antenna designs have been presented in Section IV, which cause notching in various frequency ranges. Finally, Section V presented the concept of reconfigurable antennas in UWB technology, their need, and their advantages over conventional UWB technology. A review of antenna designs and their reason for reconfiguration has been highlighted in this section. UWB technology and antennas radiating in this range are here to stay. Therefore, this article aimed at presenting the birth, growth, and most recent trends in this field.

Author Contributions: All authors contributed equally to this work. All authors have read and agreed to the published version of the manuscript.

Funding: This research received no external funding.

Institutional Review Board Statement: Not applicable.

Informed Consent Statement: Not applicable.

Data Availability Statement: Not applicable.

Conflicts of Interest: The authors declare no conflict of interest.

\section{References}

1. Federal Communications Commission (FCC). Revision of Part 15 of The Commission's Rules Regarding Ultra-Wideband Transmission Systems. In First Report and Order; ET Docket: Washington, DC, USA, 2002; pp. 98-153.

2. Moccia, A.; Vetrella, S.; Bertoni, R. Mission analysis and design of a bistatic synthetic aperture radar on board a small satellite. Acta Astronaut. 2000, 47, 819-829. [CrossRef]

3. Rush, J. Current issues in the use of the global positioning system aboard satellites. Acta Astronaut. 2000, 47, 377-387. [CrossRef]

4. Wallinga, G.; Rothwell, E.; Chen, K.-M.; Nyquist, D. Enhanced detection of a target in a sea clutter environment using a stepped, ultra-wideband signal and E-pulse cancellation. IEEE Trans. Antennas Propag. 2001, 49, 1166-1173. [CrossRef]

5. Remondo, D.; Niemegeers, I.G. Ad hoc networking in future wireless communications. Comput. Commun. 2003, 26, 36-40. [CrossRef]

6. Walke, B.H.; Kumar, V. Spectrum issues and new air interfaces. Comput. Commun. 2003, 26, 53-63. [CrossRef]

7. Tafazolli, R. (Ed.) Technologies for the Wireless Future; Wireless World Research Forum (WWRF); John Wiley \& Sons: Hoboken, NJ, USA, 2006.

8. Gschwendtner, E.; Wiesbeck, W. Ultra-broadband car antennas for communications and navigation applications. IEEE Trans. Antennas Propag. 2003, 51, 2020-2027. [CrossRef]

9. Chen, C.-C.; Rao, K.R.; Lee, R. A new ultrawide-bandwidth dielectric-rod antenna for ground-penetrating radar applications. IEEE Trans. Antennas Propag. 2003, 51,371-377. [CrossRef]

10. Kim, K.; Scott, W. Design of a resistively loaded vee dipole for ultrawide-band ground-penetrating Radar applications. IEEE Trans. Antennas Propag. 2005, 53, 2525-2532. [CrossRef]

11. Giuliano, R.; Guidoni, G.; Habib, I.; Mazzenga, F. Coexistence of an ultrawideband spread spectrum system with fixed wireless access systems. Comput. Netw. 2004, 44, 583-598. [CrossRef]

12. Lopez, J., Jr.; Raines, R.A.; Temple, M.A.; Baldwin, R.O.; Stephens, J.P., Sr. An investigation on the effects of emerging 4G transmissions on $3 \mathrm{G}$ networks. Omega 2007, 35, 706-714. [CrossRef]

13. Turkmen, M.; Yalduz, H. Design and Performance Analysis of a Flexible UWB Wearable Textile Antenna on Jeans Substrate. Int. J. Inf. Electron. Eng. 2018, 8, 15-18. [CrossRef] 
14. Mersani, A.; Osman, L.; Ribero, J.-M. Flexible UWB AMC antenna for early stage skin cancer identification. Prog. Electromagn. Res. M 2019, 80, 71-81. [CrossRef]

15. Simorangkir, R.B.; Kiourti, A.; Esselle, K.P. UWB Wearable Antenna with a Full Ground Plane Based on PDMS-Embedded Conductive Fabric. IEEE Antennas Wirel. Propag. Lett. 2018, 17, 493-496. [CrossRef]

16. Negi, D.; Khanna, R.; Kaur, J. Design and performance analysis of a conformal CPW fed wideband antenna with Mu-Negative metamaterial for wearable applications. Int. J. Microw. Wirel. Technol. 2019, 11, 806-820. [CrossRef]

17. Lin, X.; Chen, Y.; Gong, Z.; Seet, B.-C.; Huang, L.; Lu, Y. Ultrawideband Textile Antenna for Wearable Microwave Medical Imaging Applications. IEEE Trans. Antennas Propag. 2020, 68, 4238-4249. [CrossRef]

18. Klemm, M.; Troester, G. Textile UWB Antennas for Wireless Body Area Networks. IEEE Trans. Antennas Propag. 2006, 54, 3192-3197. [CrossRef]

19. Kumar, V.; Gupta, B. On-body measurements of SS-UWB patch antenna for WBAN applications. AEU-Int. J. Electron. Commun. 2016, 70, 668-675. [CrossRef]

20. Elobaid, H.A.E.; Rahim, S.K.A.; Himdi, M.; Castel, X.; Kasgari, M.A. A Transparent and Flexible Polymer-Fabric Tissue UWB Antenna for Future Wireless Networks. IEEE Antennas Wirel. Propag. Lett. 2016, 16, 1333-1336. [CrossRef]

21. Yalduz, H.; Tabaru, T.E.; Kilic, V.T.; Turkmen, M. Design and analysis of low profile and low SAR full-textile UWB wearable antenna with metamaterial for WBAN applications. AEU-Int. J. Electron. Commun. 2020, 126, 153465. [CrossRef]

22. Hossain, M.J.; Faruque, M.R.I.; Islam, M.M.; Islam, M.T.; Rahman, M.A. Bird face microstrip printed monopole antenna design for ultra wide band applications. Frequenz 2016, 70, 473-478. [CrossRef]

23. Rajagopalan, A.; Gupta, G.; Konanur, A.S.; Hughes, B.; Lazzi, G. Increasing Channel Capacity of an Ultrawideband MIMO System Using Vector Antennas. IEEE Trans. Antennas Propag. 2007, 55, 2880-2887. [CrossRef]

24. Su, S.-W.; Chou, J.-H.; Wong, K.-L. Internal Ultrawideband Monopole Antenna for Wireless USB Dongle Applications. IEEE Trans. Antennas Propag. 2007, 55, 1180-1183. [CrossRef]

25. Farwell, M.; Ross, J.; Luttrell, R.; Cohen, D.; Chin, W.; Dogaru, T. Sense through the wall system development and design considerations. J. Frankl. Inst. 2008, 345, 570-591. [CrossRef]

26. Narayanan, R.M. Through-wall radar imaging using UWB noise waveforms. J. Frankl. Inst. 2008, 345, 659-678. [CrossRef]

27. Liang, J.; Liang, Q. Sense-Through-Foliage target detection using UWB radar sensor networks. Pattern Recognit. Lett. 2010, 31, 1412-1421. [CrossRef]

28. He, X.; Jiang, T. Target identification in foliage environment using UWB radar with hybrid wavelet-ICA and SVM method. Phys. Commun. 2014, 13, 197-204. [CrossRef]

29. Li, X.; Liang, Q.; Lau, F.C. Sense-through-wall human detection using the UWB radar with sparse SVD. Phys. Commun. 2014, 13, 260-266. [CrossRef]

30. Zhang, Z.; Langer, J.-C.; Li, K.; Iskander, M. Design of Ultrawideband Mobile Phone Stubby Antenna (824 MHz-6 GHz). IEEE Trans. Antennas Propag. 2008, 56, 2107-2111. [CrossRef]

31. José, M.; Castro-Lopez, R.; Morgado, A.; Becerra-Alvarez, E.C.; del Rio, R.; Fernandez, F.V.; Perez-Verdu, B. Adaptive CMOS analog circuits for 4G mobile terminals-Review and state-of-the-art survey. Microelectron. J. 2009, 40, 156-176.

32. Chehri, A.; Fortier, P.; Tardif, P.M. UWB-based sensor networks for localization in mining environments. Ad Hoc Netw. 2009, 7, 987-1000. [CrossRef]

33. Ahmed, B.T.; Campos, J.L.M.; Ruiz-Cruz, J.A. Impact of Ultra Wide Band emission on WiMAX systems at 2.5 and 3.5 GHz. Comput. Netw. 2010, 54, 1573-1583. [CrossRef]

34. Van Der Linde, E.; Hancke, G. An investigation of Bluetooth mergence with Ultra Wideband. Ad Hoc Netw. 2011, 9, 852-863. [CrossRef]

35. Fuchs, C.; Aschenbruck, N.; Martini, P.; Wieneke, M. Indoor tracking for mission critical scenarios: A survey. Pervasive Mob. Comput. 2011, 7, 1-15. [CrossRef]

36. Cheng, T.; Venugopal, M.; Teizer, J.; Vela, P.A. Performance evaluation of ultra wideband technology for construction resource location tracking in harsh environments. Autom. Constr. 2011, 20, 1173-1184. [CrossRef]

37. Chunming, W.; Guoliang, D. The Study of UWB Radar Life-Detection for Searching Human Subjects. Energy Procedia 2012, 17, 1028-1033. [CrossRef]

38. Sun, J.; Li, M. Life detection and location methods using UWB impulse radar in a coal mine. Min. Sci. Technol. 2011, 21, 687-691. [CrossRef]

39. Liu, L.; Liu, Z.; Xie, H.; Barrowes, B.; Bagtzoglou, A.C. Numerical simulation of UWB impulse radar vital sign detection at an earthquake disaster site. Ad Hoc Netw. 2014, 13, 34-41. [CrossRef]

40. Rabbani, M.S.; Ghafouri-Shiraz, H. Accurate remote vital sign monitoring with $10 \mathrm{GHz}$ ultra-wide patch antenna array. AEU-Int. J. Electron. Commun. 2017, 77, 36-42. [CrossRef]

41. Imran, A.I.; Elwi, T.A. A cylindrical wideband slotted patch antenna loaded with Frequency Selective Surface for MRI applications. Eng. Sci. Technol. Int. J. 2017, 20, 990-996. [CrossRef]

42. Srikanth, B.S.; Gurung, S.B.; Manu, S.; Gowthami, G.N.; Ali, T.; Pathan, S. A slotted UWB monopole antenna with truncated ground plane for breast cancer detection. Alex. Eng. J. 2020, 59, 3767-3780. [CrossRef]

43. Moosazadeh, M.; Kharkovsky, S.; Case, J.T.; Samali, B. Miniaturized UWB Antipodal Vivaldi Antenna and Its Application for Detection of Void Inside Concrete Specimens. IEEE Antennas Wirel. Propag. Lett. 2016, 16, 1317-1320. [CrossRef] 
44. Ghendir, S.; Sbaa, S.; Al-Sherbaz, A.; Ajgou, R.; Chemsa, A. Towards 5G wireless systems: A modified Rake receiver for UWB indoor multipath channels. Phys. Commun. 2019, 35, 100715. [CrossRef]

45. Akbarpour, A.; Chamaani, S. Ultrawideband Circularly Polarized Antenna for Near-Field SAR Imaging Applications. IEEE Trans. Antennas Propag. 2020, 68, 4218-4228. [CrossRef]

46. Maitre, J.; Bouchard, K.; Bertuglia, C.; Gaboury, S. Recognizing activities of daily living from UWB radars and deep learning. Expert Syst. Appl. 2021, 164, 113994. [CrossRef]

47. Hirt, W. Ultra-wideband radio technology: Overview and future research. Comput. Commun. 2003, 26, 46-52. [CrossRef]

48. Chung, L.; Chang, T.; Burnside, W. An ultrawide-bandwidth tapered resistive TEM horn antenna. IEEE Trans. Antennas Propag. 2000, 48, 1848-1857. [CrossRef]

49. Ghorbani, K.; Waterhouse, R. Ultrabroadband printed (ubp) antenna. IEEE Trans. Antennas Propag. 2002, 50, 1697-1705. [CrossRef]

50. Ammann, M.; Chen, Z.N. A wide-band shorted planar monopole with bevel. IEEE Trans. Antennas Propag. 2003, 51, 901-903. [CrossRef]

51. Altshuler, E.; Linden, D. An Ultrawide-Band Impedance-Loaded Genetic Antenna. IEEE Trans. Antennas Propag. 2004, 52, 3147-3150. [CrossRef]

52. Lee, K.-H.; Chen, C.-C.; Teixeira, F.; Lee, R. Modeling and Investigation of a Geometrically Complex UWB GPR Antenna Using FDTD. IEEE Trans. Antennas Propag. 2004, 52, 1983-1991. [CrossRef]

53. Suh, S.-Y.; Stutzman, W.; Davis, W. A New Ultrawideband Printed Monopole Antenna: The Planar Inverted Cone Antenna (PICA). IEEE Trans. Antennas Propag. 2004, 52, 1361-1365. [CrossRef]

54. Venkatarayalu, N.; Chen, C.-C.; Teixeira, F.; Lee, R. Numerical Modeling of Ultrawide-Band Dielectric Horn Antennas Using FDTD. IEEE Trans. Antennas Propag. 2004, 52, 1318-1323. [CrossRef]

55. Ma, T.-G.; Jeng, S.-K. A printed dipole antenna with tapered slot feed for ultrawide-band applications. IEEE Trans. Antennas Propag. 2005, 53, 3833-3836. [CrossRef]

56. Liang, J.; Chiau, C.C.; Chen, X.; Parini, C.G. Study of a printed circular disc monopole antenna for UWB systems. IEEE Trans. Antennas Propag. 2005, 53, 3500-3504. [CrossRef]

57. Chung, K.; Pyun, S.; Choi, J. Design of an ultrawide-band TEM horn antenna with a microstrip-type balun. IEEE Trans. Antennas Propag. 2005, 53, 3410-3413. [CrossRef]

58. Ying, C.; Zhang, Y. A planar antenna in LTCC for single-package ultrawide-band radio. IEEE Trans. Antennas Propag. 2005, 53, 3089-3093. [CrossRef]

59. Behdad, N.; Sarabandi, K. A compact antenna for ultrawide-band applications. IEEE Trans. Antennas Propag. 2005, 53, $2185-2192$. [CrossRef]

60. Wong, K.-L.; Wu, C.-H.; Su, S.-W. Ultrawide-band square planar metal-plate monopole antenna with a trident-shaped feeding strip. IEEE Trans. Antennas Propag. 2005, 53, 1262-1269. [CrossRef]

61. Andrieu, J.; Nouvet, S.; Bertrand, V.; Beillard, B.; Jecko, B. Transient characterization of a novel ultrawide-band antenna: The scissors antenna. IEEE Trans. Antennas Propag. 2005, 53, 1254-1261. [CrossRef]

62. Ma, T.-G.; Jeng, S.-K. Planar miniature tapered-slot-fed annular slot antennas for ultrawide-band radios. IEEE Trans. Antennas Propag. 2005, 53, 1194-1202. [CrossRef]

63. Li, P.; Liang, J.; Chen, X. Study of Printed Elliptical/Circular Slot Antennas for Ultrawideband Applications. IEEE Trans. Antennas Propag. 2006, 54, 1670-1675. [CrossRef]

64. Thomas, K.; Lenin, N.; Sivaramakrishnan, R. Ultrawideband Planar Disc Monopole. IEEE Trans. Antennas Propag. 2006, 54, 1339-1341. [CrossRef]

65. Nikolaou, S.; Ponchak, G.; Papapolymerou, J.; Tentzeris, M. Conformal Double Exponentially Tapered Slot Antenna (DETSA) on LCP for UWB Applications. IEEE Trans. Antennas Propag. 2006, 54, 1663-1669. [CrossRef]

66. Rambabu, K.; Thiart, H.A.; Bornemann, J.; Yu, S.Y. Ultrawideband Printed-Circuit Antenna. IEEE Trans. Antennas Propag. 2006, 54, 3908-3911. [CrossRef]

67. Mao, S.-G.; Chen, S.-L. Frequency- and Time-Domain Characterizations of Ultrawideband Tapered Loop Antennas. IEEE Trans. Antennas Propag. 2007, 55, 3698-3701. [CrossRef]

68. Qu, S.-W.; Li, J.-L.; Chen, J.-X.; Xue, Q. Ultrawideband Strip-Loaded Circular Slot Antenna with Improved Radiation Patterns. IEEE Trans. Antennas Propag. 2007, 55, 3348-3353. [CrossRef]

69. Ruvio, G.; Ammann, M. A Novel Wideband Semi-Planar Miniaturized Antenna. IEEE Trans. Antennas Propag. 2007, 55, 2679-2685. [CrossRef]

70. Bruni, S.; Neto, A.; Marliani, F. The ultrawideband leaky lens antenna. IEEE Trans. Antennas Propag. 2007, 55, 2642-2653. [CrossRef]

71. Ling, C.-W.; Lo, W.-H.; Yan, R.-H.; Chung, S.-J. Planar Binomial Curved Monopole Antennas for Ultrawideband Communication. IEEE Trans. Antennas Propag. 2007, 55, 2622-2624. [CrossRef]

72. Blech, M.D.; Eibert, T.F. A Dipole Excited Ultrawideband Dielectric Rod Antenna with Reflector. IEEE Trans. Antennas Propag. 2007, 55, 1948-1954. [CrossRef]

73. Ray, K.P.; Ranga, Y. Ultrawideband Printed Elliptical Monopole Antennas. IEEE Trans. Antennas Propag. 2007, 55, 1189-1192. [CrossRef] 
74. Ni Low, X.; Chen, Z.N.; Toh, W.K. Ultrawideband Suspended Plate Antenna with Enhanced Impedance and Radiation Performance. IEEE Trans. Antennas Propag. 2008, 56, 2490-2495. [CrossRef]

75. See, T.S.P.; Chen, Z.N. An Electromagnetically Coupled UWB Plate Antenna. IEEE Trans. Antennas Propag. 2008, 56, 1476-1479. [CrossRef]

76. Wu, Q.; Jin, R.; Geng, J.; Ding, M. Printed Omni-Directional UWB Monopole Antenna with Very Compact Size. IEEE Trans. Antennas Propag. 2008, 56, 896-899. [CrossRef]

77. Kwon, D.-H.; Balzovsky, E.V.; Buyanov, Y.I.; Kim, Y.; Koshelev, V.I. Small Printed Combined Electric-Magnetic Type Ultrawideband Antenna with Directive Radiation Characteristics. IEEE Trans. Antennas Propag. 2008, 56, 237-241. [CrossRef]

78. Eskandari, H.; Azarmanesh, M.N. Bandwidth enhancement of a printed wide-slot antenna with small slots. AEU-Int. J. Electron. Commun. 2009, 63, 896-900. [CrossRef]

79. Liu, W.; Yin, Y.; Xu, W.; Zuo, S. Compact Open-Slot Antenna with Bandwidth Enhancement. IEEE Antennas Wirel. Propag. Lett. 2011, 10, 850-853. [CrossRef]

80. Sowmya, G.A.; Kamath, A.; Keshava, A.; Kumar, O.P.; Vincent, S.; Ali, T. A circular monopole patch antenna loaded with inverted L-shaped stub for GPS application. Bull. Electr. Eng. Inform. 2020, 9, 1950-1957. [CrossRef]

81. Saha, C.; Siddiqui, J.Y.; Antar, Y.M. Multifunctional Ultrawideband Antennas: Trends, Techniques and Applications; CRC Press: Boca Raton, FL, USA, 2019.

82. Lin, Y.-C.; Hung, K.-J. Compact Ultrawideband Rectangular Aperture Antenna and Band-Notched Designs. IEEE Trans. Antennas Propag. 2006, 54, 3075-3081. [CrossRef]

83. Kim, K.-H.; Park, S.-O. Analysis of the Small Band-Rejected Antenna with the Parasitic Strip for UWB. IEEE Trans. Antennas Propag. 2006, 54, 1688-1692. [CrossRef]

84. Qiu, J.; Du, Z.; Lu, J.; Gong, K. A Planar Monopole Antenna Design with Band-Notched Characteristic. IEEE Trans. Antennas Propag. 2006, 54, 288-292. [CrossRef]

85. Ma, T.-G.; Wu, S.-J. Ultrawideband Band-Notched Folded Strip Monopole Antenna. IEEE Trans. Antennas Propag. 2007, 55, 2473-2479. [CrossRef]

86. Lui, W.-J.; Cheng, C.-H.; Zhu, H.-B. Improved Frequency Notched Ultrawideband Slot Antenna Using Square Ring Resonator. IEEE Trans. Antennas Propag. 2007, 55, 2445-2450. [CrossRef]

87. Eshtiaghi, R.; Zaker, R.; Nouronia, J.; Ghobadi, C. UWB semi-elliptical printed monopole antenna with subband rejection filter. AEU-Int. J. Electron. Commun. 2010, 64, 133-141. [CrossRef]

88. Azim, R.; Islam, M.T.; Misran, N. Compact Tapered-Shape Slot Antenna for UWB Applications. IEEE Antennas Wirel. Propag. Lett. 2011, 10, 1190-1193. [CrossRef]

89. Agarwal, M.; Dhanoa, J.K.; Khandelwal, M.K. Ultrawide band two-port MIMO diversity antenna with triple notch bands, stable gain and suppressed mutual coupling. AEU-Int. J. Electron. Commun. 2020, 120, 153225. [CrossRef]

90. Ghatak, R.; Karmakar, A.; Poddar, D. Hexagonal boundary Sierpinski carpet fractal shaped compact ultrawideband antenna with band rejection functionality. AEU-Int. J. Electron. Commun. 2013, 67, 250-255. [CrossRef]

91. Roy, B.; Bhattacharya, A.; Chowdhury, S.; Bhattacharjee, A. Wideband Snowflake slot antenna using Koch iteration technique for wireless and C-band applications. AEU-Int. J. Electron. Commun. 2016, 70, 1467-1472. [CrossRef]

92. Rajabloo, H.; Kooshki, V.A.; Oraizi, H. Compact microstrip fractal Koch slot antenna with ELC coupling load for triple band application. AEU-Int. J. Electron. Commun. 2017, 73, 144-149. [CrossRef]

93. Zarrabi, F.B.; Mansouri, Z.; Gandji, N.P.; Kuhestani, H. Triple-notch UWB monopole antenna with fractal Koch and T-shaped stub. AEU-Int. J. Electron. Commun. 2016, 70, 64-69. [CrossRef]

94. Sharma, M.; Awasthi, Y.K.; Singh, H.; Kumar, R.; Kumari, S. Compact printed high rejection triple band-notch UWB antenna with multiple wireless applications. Eng. Sci. Technol. Int. J. 2016, 19, 1626-1634. [CrossRef]

95. Tang, Z.; Wu, X.; Zhan, J.; Hu, S.; Xi, Z.; Liu, Y. Compact UWB-MIMO Antenna with High Isolation and Triple Band-Notched Characteristics. IEEE Access 2019, 7, 19856-19865. [CrossRef]

96. Kumar, A.; Ansari, A.Q.; Kanaujia, B.K.; Kishor, J.; Kumar, S. An ultra-compact two-port UWB-MIMO antenna with dual band-notched characteristics. AEU-Int. J. Electron. Commun. 2020, 114, 152997. [CrossRef]

97. Cho, Y.J.; Kim, K.H.; Choi, D.H.; Lee, S.S.; Park, S.-O. A Miniature UWB Planar Monopole Antenna With 5-GHz Band-Rejection Filter and the Time-Domain Characteristics. IEEE Trans. Antennas Propag. 2006, 54, 1453-1460. [CrossRef]

98. Ma, T.-G.; Tseng, C.-H. An Ultrawideband Coplanar Waveguide-Fed Tapered Ring Slot Antenna. IEEE Trans. Antennas Propag. 2006, 54, 1105-1110. [CrossRef]

99. Hong, C.-Y.; Ling, C.-W.; Tarn, I.-Y.; Chung, S.-J. Design of a Planar Ultrawideband Antenna with a New Band-Notch Structure. IEEE Trans. Antennas Propag. 2007, 55, 3391-3397. [CrossRef]

100. Zhang, J.-P.; Xu, Y.-S.; Wang, W.-D. Microstrip-Fed Semi-Elliptical Dipole Antennas for Ultrawideband Communications. IEEE Trans. Antennas Propag. 2008, 56, 241-244. [CrossRef]

101. Soltani, S.; Azarmanesh, M.; Lotfi, P.; Dadashzadeh, G. Two novel very small monopole antennas having frequency band notch function using DGS for UWB application. AEU-Int. J. Electron. Commun. 2011, 65, 87-94. [CrossRef]

102. Chitra, R.J.; Nagarajan, V. Double L-slot microstrip patch antenna array for WiMAX and WLAN applications. Comput. Electr. Eng. 2013, 39, 1026-1041. [CrossRef] 
103. Kang, L.; Li, H.; Wang, X.; Shi, X. Compact Offset Microstrip-Fed MIMO Antenna for Band-Notched UWB Applications. IEEE Antennas Wirel. Propag. Lett. 2015, 14, 1754-1757. [CrossRef]

104. Huang, H.; Liu, Y.; Zhang, S.; Gong, S. Uniplanar Differentially Driven Ultrawideband Polarization Diversity Antenna with Band-Notched Characteristics. IEEE Antennas Wirel. Propag. Lett. 2014, 14, 563-566. [CrossRef]

105. Bakariya, P.S.; Dwari, S.; Sarkar, M. Triple band notch UWB printed monopole antenna with enhanced bandwidth. AEU-Int. J. Electron. Commun. 2015, 69, 26-30. [CrossRef]

106. Wang, Z.; Liu, J.; Yin, Y. Triple band-notched UWB antenna using novel asymmetrical resonators. AEU-Int. J. Electron. Commun. 2016, 70, 1630-1636. [CrossRef]

107. Yadav, A.; Sethi, D.; Khanna, R. Slot loaded UWB antenna: Dual band notched characteristics. AEU-Int. J. Electron. Commun. 2016, 70, 331-335. [CrossRef]

108. Peng, L.; Wen, B.-J.; Li, X.-F.; Jiang, X.; Li, S.-M. CPW Fed UWB Antenna by EBGs With Wide Rectangular Notched-Band. IEEE Access 2016, 4, 9545-9552. [CrossRef]

109. Yang, Z.; Jingjian, H.; Weiwei, W.; Naichang, Y. An antipodal Vivaldi antenna with band-notched characteristics for ultra-wideband applications. AEU-Int. J. Electron. Commun. 2017, 76, 152-157. [CrossRef]

110. Yang, B.; Qu, S. A compact integrated Bluetooth UWB dual-band notch antenna for automotive communications. AEU-Int. J. Electron. Commun. 2017, 80, 104-113. [CrossRef]

111. Awad, N.M.; Abdelazeez, M.K. Multislot microstrip antenna for ultra-wide band applications. J. King Saud Univ.-Eng. Sci. 2018, 30, 38-45. [CrossRef]

112. Mewara, H.S.; Deegwal, J.K.; Sharma, M.M. A slot resonators based quintuple band-notched Y-shaped planar monopole ultra-wideband antenna. AEU-Int. J. Electron. Commun. 2018, 83, 470-478. [CrossRef]

113. Yadav, D.; Abegaonkar, M.P.; Koul, S.K.; Tiwari, V.; Bhatnagar, D. A compact dual band-notched UWB circular monopole antenna with parasitic resonators. AEU-Int. J. Electron. Commun. 2018, 84, 313-320. [CrossRef]

114. Atallah, H.A.; Abdel-Rahman, A.B.; Yoshitomi, K.; Pokharel, R.K. CPW-Fed UWB antenna with sharp and high rejection multiple notched bands using stub loaded meander line resonator. AEU-Int. J. Electron. Commun. 2018, 83, 22-31. [CrossRef]

115. Mewara, H.S.; Jhanwar, D.; Sharma, M.M.; Deegwal, J.K. A printed monopole ellipzoidal UWB antenna with four band rejection characteristics. AEU-Int. J. Electron. Commun. 2018, 83, 222-232. [CrossRef]

116. Jaglan, N.; Gupta, S.D.; Thakur, E.; Kumar, D.; Kanaujia, B.K.; Srivastava, S. Triple band notched mushroom and uniplanar EBG structures based UWB MIMO/Diversity antenna with enhanced wide band isolation. AEU-Int. J. Electron. Commun. 2018, 90, 36-44. [CrossRef]

117. Benavides, J.B.; Lituma, R.A.; Chasi, P.A.; Guerrero, L.F. A Novel Modified Hexagonal Shaped Fractal Antenna with Multi Band Notch Characteristics for UWB Applications. In Proceedings of the 2018 IEEE-APS Topical Conference on Antennas and Propagation in Wireless Communications (APWC), Cartagena, Colombia, 10-14 September 2018; pp. 830-833.

118. El-Hameed, A.A.; Wahab, M.; Elboushi, A.; Elpeltagy, M.S. Miniaturized triple band-notched quasi-self complementary fractal antenna with improved characteristics for UWB applications. AEU-Int. J. Electron. Commun. 2019, 108, 163-171. [CrossRef]

119. Suriya, I.; Anbazhagan, R. Inverted-A based UWB MIMO antenna with triple-band notch and improved isolation for WBAN applications. AEU-Int. J. Electron. Commun. 2019, 99, 25-33. [CrossRef]

120. Kumar, R.; Kamatham, Y. Fork shaped with inverted L-stub resonator UWB antenna for WiMAX/WLAN rejection band. AEU-Int. J. Electron. Commun. 2019, 110, 152881. [CrossRef]

121. Sanyal, R.; Sarkar, P.P.; Sarkar, S. Octagonal nut shaped monopole UWB antenna with sextuple band notched characteristics. AEU-Int. J. Electron. Commun. 2019, 110, 152833. [CrossRef]

122. Kumar, P.; Ali, T.; Pai, M.M.M. Electromagnetic Metamaterials: A New Paradigm of Antenna Design. IEEE Access 2021, 9 , 18722-18751. [CrossRef]

123. Modak, S.; Khan, T.; Laskar, R.H. Penta-notched UWB Monopole Antenna Using EBG Structures and Fork-Shaped Slots. Radio Sci. 2020, 55, 1-11. [CrossRef]

124. Alizadeh, F.; Ghobadi, C.; Nourinia, J.; Abdi, H.; Mohammadi, B. UWB dual-notched planar antenna by utilizing compact open meander slitted EBG structure. AEU-Int. J. Electron. Commun. 2021, 136, 153715. [CrossRef]

125. Li, W.T.; Hei, Y.Q.; Feng, W.; Shi, X.W. Planar Antenna for 3G/Bluetooth/WiMAX and UWB Applications with Dual Band-Notched Characteristics. IEEE Antennas Wirel. Propag. Lett. 2012, 11, 61-64. [CrossRef]

126. Yadav, A.; Agrawal, S.; Yadav, R. SRR and S-shape slot loaded triple band notched UWB antenna. AEU-Int. J. Electron. Commun. 2017, 79, 192-198. [CrossRef]

127. Rahman, M.; Khan, W.T.; Imran, M. Penta-notched UWB antenna with sharp frequency edge selectivity using combination of SRR, CSRR, and DGS. AEU-Int. J. Electron. Commun. 2018, 93, 116-122. [CrossRef]

128. Li, Z.; Yin, C.; Zhu, X. Compact UWB MIMO Vivaldi Antenna with Dual Band-Notched Characteristics. IEEE Access 2019, 7, 38696-38701. [CrossRef]

129. Salamin, M.A.; Ali, W.A.; Das, S.; Zugari, A. Design and investigation of a multi-functional antenna with variable wideband/notched UWB behavior for WLAN/X-band/UWB and Ku-band applications. AEU-Int. J. Electron. Commun. 2019, 111, 152895. [CrossRef]

130. Luo, S.; Chen, Y.; Wang, D.; Liao, Y.; Li, Y. A monopole UWB antenna with sextuple band-notched based on SRRs and U-shaped parasitic strips. AEU-Int. J. Electron. Commun. 2020, 120, 153206. [CrossRef] 
131. Serria, E.A.; Hussein, M.I. Implications of Metamaterial on Ultra-Wide Band Microstrip Antenna Performance. Crystals 2020, 10, 677. [CrossRef]

132. Ebadzadeh, S.R.; Zehforoosh, Y.; Mohammadifar, M.; Zavvari, M.; Mohammady, P. A Compact UWB Monopole Antenna with Rejected WLAN Band using Split-Ring Resonator and Assessed by Analytic Hierarchy Process Method. J. Microw. Optoelectron. Electromagn. Appl. 2017, 16, 592-601. [CrossRef]

133. Bakali, H.E.O.E.; Zakriti, A.; Farkhsi, A.; Dkiouak, A.; El Ouahabi, A.M. Design and Realization of Dual Band Notch UWB MIMO Antenna In 5G And Wi-Fi 6E by Using Hybrid Technique. Prog. Electromagn. Res. C 2021, 116, 1-12. [CrossRef]

134. Zhou, J.-Y.; Wang, Y.; Xu, J.-M.; Du, A.C. A Cpw-Fed Uwb-Mimo Antenna with High Isolation and Dual Band-Notched Characteristic. Prog. Electromagn. Res. M 2021, 102, 27-37. [CrossRef]

135. Abbas, A.; Hussain, N.; Lee, J.; Park, S.G.; Kim, N. Triple Rectangular Notch UWB Antenna Using EBG and SRR. IEEE Access 2021, 9, 2508-2515. [CrossRef]

136. Wang, S.; Li, K.; Kong, F.; Du, L. A miniaturized triple-band planar antenna combing single-cell metamaterial structure and defected ground plane for WLAN/WiMAX applications. J. Electromagn. Waves Appl. 2021, 35, 357-370. [CrossRef]

137. Hassan, M.M.; Rasool, M.; Asghar, M.U.; Zahid, Z.; Khan, A.A.; Rashid, I.; Rauf, A.; Bhatti, F.A. A novel UWB MIMO antenna array with band notch characteristics using parasitic decoupler. J. Electromagn. Waves Appl. 2019, 34, 1225-1238. [CrossRef]

138. Wahab, M.G.; Swelam, W.; Abdeazeem, M. Novel miniaturized UWB antenna with triple band-notched characteristics utilizing SRR and folded U-shaped slot. In Proceedings of the 2017 Progress in Electromagnetics Research Symposium-Spring (PIERS), St. Petersburg, Russia, 22-25 May 2017; pp. 1176-1180.

139. Islam, M.M.; Faruque, M.R.I.; Islam, M.; Islam, M.T. A Compact 5.5 GHz Band-Rejected UWB Antenna Using Complementary Split Ring Resonators. Sci. World J. 2014, 2014, 1-8. [CrossRef]

140. Bernhard, J.T. Reconfigurable Antennas. Synth. Lect. Antennas 2007, 2, 1-66. [CrossRef]

141. Parchin, N.O.; Basherlou, H.J.; Al-Yasir, Y.I.A.; Abd-Alhameed, R.A.; Abdulkhaleq, A.M.; Noras, J.M. Recent Developments of Reconfigurable Antennas for Current and Future Wireless Communication Systems. Electronics 2019, 8, 128. [CrossRef]

142. Haupt, R.L.; Lanagan, M. Reconfigurable antennas. IEEE Antennas Propag. Mag. 2013, 55, 49-61. [CrossRef]

143. Ali, T.; Pathan, S.; Biradar, R.C. Multiband, frequency reconfigurable, and metamaterial antennas design techniques: Present and future research directions. Internet Technol. Lett. 2018, 1, e19. [CrossRef]

144. Al-Husseini, M.; Costantine, J.; Christodoulou, C.G.; Barbin, S.E.; El-Hajj, A.; Kabalan, K.Y. A reconfigurable frequency-notched UWB antenna with split-ring resonators. In Proceedings of the2010 Asia-Pacific Microwave Conference, Yokohama, Japan, 7-10 December 2010; pp. 618-621.

145. Elsheakh, D.N.; Elsadek, H.A.; Abdallah, E.A. Reconfigurable microstrip monopole patch antenna with electromagnetic band-gap structure design for ultrawideband wireless communication systems. Microw. Opt. Technol. Lett. 2011, 53, 2466-2471. [CrossRef]

146. Naser-Moghadasi, M.; Haraty, M.R.; Momeni, S.M.S.; Virdee, B.S. Novel compact UWB antenna with reconfigurable dual-band notches using pin diode switches actuated without $\mathrm{\lambda g} / 4 \mathrm{DC}$ bias lines. Microw. Opt. Technol. Lett. 2012, 54, 2392-2397. [CrossRef]

147. Al-Husseini, M.; Safatly, L.; Ramadan, A.; El-Hajj, A.; Kabalan, K.; Christodoulou, C.G. Reconfigurable Filter Antennas for Pulse Adaptation in UWB Cognitive Radio Systems. Prog. Electromagn. Res. B 2012, 37, 327-342. [CrossRef]

148. Wu, Z.H.; Wei, F.; Shi, X.-W.; Li, W.-T. A Compact Quad Band-Notched UWB Monopole Antenna Loaded One Lateral L-Shaped Slot. Prog. Electromagn. Res. 2013, 139, 303-315. [CrossRef]

149. Shahine, M.Y.A.; Al-Husseini, M.; Kabalan, K.; El-Hajj, A. Dielectric resonator antennas with band rejection and frequency reconfigurability. Prog. Electromagn. Res. C 2014, 46, 101-108. [CrossRef]

150. Aghdam, S.A.; Bagby, J.S. Resonator Type for the Creation of a Potentially Reconfigurable Filtering Band in a UWB Antenna. Prog. Electromagn. Res. Lett. 2015, 52, 17-21. [CrossRef]

151. Horestani, A.K.; Shaterian, Z.; Naqui, J.; Martin, F.; Fumeaux, C. Reconfigurable and Tunable S-Shaped Split-Ring Resonators and Application in Band-Notched UWB Antennas. IEEE Trans. Antennas Propag. 2016, 64, 3766-3776. [CrossRef]

152. Srivastava, G.; Mohan, A.; Chakrabarty, A. Compact Reconfigurable UWB Slot Antenna for Cognitive Radio Applications. IEEE Antennas Wirel. Propag. Lett. 2016, 16, 1139-1142. [CrossRef]

153. Verma, A.; Parihar, M.S. Multifunctional Antenna with Reconfigurable Ultra-Wide Band Characteristics. Radioengineering 2017, 26, 647-654. [CrossRef]

154. Toktas, A.; Yerlikaya, M. A compact reconfigurable ultra-wideband G-shaped printed antenna with band-notched characteristic. Microw. Opt. Technol. Lett. 2019, 61, 245-250. [CrossRef]

155. Magray, M.I.; Muzaffar, K.; Wani, Z.; Singh, R.K.; Karthikeya, G.S.; Koul, S.K. Compact frequency reconfigurable triple band notched monopole antenna for ultrawideband applications. Int. J. Microw. Comput. Eng. 2019, 29, 21942. [CrossRef]

156. Fertas, K.; Ghanem, F.; Azrar, A.; Aksas, R. UWB antenna with sweeping dual notch based on metamaterial SRR fictive rotation. Microw. Opt. Technol. Lett. 2020, 62, 956-963. [CrossRef]

157. Shome, P.P.; Khan, T.; Laskar, R.H. CSRR-loaded UWB monopole antenna with electronically tunable triple band-notch characteristics for cognitive radio applications. Microw. Opt. Technol. Lett. 2020, 62, 2919-2929. [CrossRef]

158. Medkour, H.; Cheniti, M.; Narbudowicz, A.; Das, S.; Vandelle, E.; Vuong, T.P. Coplanar waveguide-based ultra-wide band antenna with switchable filtering of WiMAX 3.5 GHz and WLAN 5 GHz signals. Microw. Opt. Technol. Lett. 2020, 62, 2398-2404. [CrossRef] 